\title{
Review
}

\section{Natural products possessing protein tyrosine phosphatase 1B (PTP1B) inhibitory activity found in the last decades}

\author{
Cheng-shi JIANG", Lin-fu LIANG", Yue-wei GUO* \\ State Key Laboratory of Drug Research, Shanghai Institute of Materia Medica, Chinese Academy of Sciences, Shanghai 201203, \\ China
}

This article provides an overview of approximately 300 secondary metabolites with inhibitory activity against protein tyrosine phosphatase 1B (PTP1B), which were isolated from various natural sources or derived from synthetic process in the last decades. The structure-activity relationship and the selectivity of some compounds against other protein phosphatases were also discussed. Potential pharmaceutical applications of several PTP1B inhibitors were presented.

Keywords: natural products; phytochemistry; protein tyrosine phosphatase 1B (PTP1B); inhibitor; structure-activity relationship (SAR); type 2 diabetes; obesity

Acta Pharmacologica Sinica (2012) 33: 1217-1245; doi: 10.1038/aps.2012.90; published online 3 Sep 2012

\section{Introduction}

Type 2 diabetes is a chronic disorder characterized by hyperglycemia associated with a gradual decline in insulin sensitivity and/or insulin secretion. Long-term complications from hyperglycemia can lead to an increased risk of heart attack, stroke, amputation, and kidney failure. According to statistics, more than 220 million people worldwide have diabetes. In 2004, an estimated 3.4 million people died from consequences of hyperglycemia, and this rate continues to increase each year. The WHO projected that diabetes death rates would double between 2005 and 2030. There are four main types of diabetes, including type 1 , type 2 , gestational diabetes, and drug-induced or chronic pancreatitis-induced diabetes. Type 2 diabetes accounts for $90 \%$ the cases of diabetes around the world $^{[1]}$, with obesity contributing to approximately $55 \%$ of the cases of type 2 diabetes ${ }^{[2]}$. It has been suggested that replacing saturated fats and trans fatty acids with unsaturated fats has beneficial effects on insulin sensitivity and may reduce the risk of type 2 diabetes $^{[3]}$. Thus, it is not surprising that considerable efforts have been made to find drug targets or candidates to treat or cure type 2 diabetes and obesity. Natural products have proved to be an important source of new drugs ${ }^{[4]}$. An

\footnotetext{
\#These two authors contributed equally to this article.

* To whom correspondence should be addressed.

E-mail ywguo@mail.shcnc.ac.cn

Received 2012-02-16 Accepted 2012-06-08
}

article written by Jung et al reviewed medicinal plants that have shown experimental or clinical anti-diabetic activity and that have been used in traditional systems of medicine ${ }^{[5]}$.

Reversible protein tyrosine phosphorylation catalyzed by the coordinated actions of protein tyrosine kinases (PTKs) and phosphatases (PTPs) is important for the regulation of signaling events. Consequently, cellular pathways regulated by tyrosine phosphorylation offer many drug targets for developing novel therapeutics ${ }^{[6]}$. PTPs are enzymes that catalyze protein tyrosine dephosphorylation. In humans, more than one hundred PTPs exist and function as either negative or positive modulators in various signal transduction pathways ${ }^{[7]}$. Among the various members of the PTP superfamily, PTP1B is considered to be a negative regulator of insulin receptor (IR) signaling. PTP1B is a promising drug target for the treatment of type 2 diabetes and obesity and is also involved in cancer $^{[8,9]}$.

A systematic literature search revealed that various natural compounds were reported to exhibit PTP1B inhibitory activity. There are several reviews regarding the development of PTP1B inhibitors but most of them focused on synthetic PTP1B inhibitors ${ }^{[6,9-15]}$. Only one review, written by Thareja et al, briefly reviewed approximately 50 natural PTP1B inhibitors $^{[15]}$. According to our literature search, sulfircin 236, a sesterterpene sulfate isolated as its $N, N$-dimethylguanidinium salt from a deep-water sponge Ircinia (unknown species) collected from Andros, Bahamas, appears to be the first reported 
natural product with PTP1B inhibitory activity ${ }^{[16]}$. In 2002, five natural flavonoids were reported as PTP1B inhibitors ${ }^{[17]}$. Since then, approximately 300 new or known natural products, which possess PTP1B inhibitory activity, have been isolated and identified from various natural resources. Many of the products identified are characterized by remarkable structural diversity with rare carbon and heterocyclic skeletons. Because of the rapid development of natural PTP1B inhibitors and the lack of a comprehensive review regarding natural PTP1B inhibitors until now, it appears a comprehensive review is urgently needed on this topic. This review first gives a brief introduction on the definition and function of PTP1B, and then focuses on the isolation, bioactivities, and synthetic progress of the natural PTP1B inhibitors reported. The structure-activityrelationship (SAR) and the selectivity of some compounds against other protein phosphatases (PPs) are mentioned as well. (In the interest of space, if the activity or inhibitory activity below is not specified, it means PTP1B inhibitory activity.)

\section{Structural biology, mechanism of PTP1B, and its validation as a drug target for diabetes and obesity}

The structural biology, mechanism of PTP1B, and its validation as a drug target for diabetes and obesity have been discussed in detail in several reviews ${ }^{[6,12,15,18,19]}$. Nevertheless, a brief introduction on PTP1B is presented below.

PTP1B was the first PTP to be isolated in its pure form. The structure of PTP1B was elucidated by X-ray crystallography in 1994, and it has served as a model to illustrate several of the properties of PTPs ${ }^{[20]}$. The structure consists of 435 amino acids with the catalytic domain comprised of residues 30 to 278 and the $35 \mathrm{COOH}$-terminal residues target the enzyme to the cytoplasmic face of the endoplamic reticulum. The active site of PTP1B is approximately 8 to $9 \AA$ deep and is defined by residues 214 to 221 (P-loop, phosphate binding loop, HisCys-Ser-Ala-Gly-Ile-Gly-Arg). The phosphate group of the substrate forms a series of hydrogen bonds with the backbone amide protons of the P-loop and Arg-221. Upon binding of the substrate, the WPD loop (residues 79-187) shifts $10 \AA$ to cover the phenyl phosphate group. This results in Asp-181 being in position to act as a general acid and protonate the ester oxygen. Cys-215 attacks the phosphorous atom resulting in cleavage of the $\mathrm{P}-\mathrm{O}$ bond and formation of a phosphocysteine intermediate that is then hydrolyzed to give the final products. A number of other residues contribute significantly to peptide substrate recognition, such as Phe182, Tyr46, Lys120, Gln262, Val49, Arg47, and Asp181, by a mixture of hydrophobic, electrostatic and hydrogen-bonding interactions. Studies with phosphotyrosine (pTyr or $\mathrm{pY}$ )-bearing peptides indicate that PTP1B has a preference for acidic residues at several positions $\mathrm{N}$-terminal to the pTyr residue ${ }^{[21]}$.

Substantial evidence indicates that PTP1B, as a negative regulator in both insulin and leptin signaling, is a promising drug target for type 2 diabetes and obesity. In the insulin signaling pathway, PTP1B can associate with and dephosphorylate activated IRs or insulin receptor substrates (IRSs). In the leptin pathway, it binds and dephosphorylates JAK2, which is downstream of the receptor. Overexpression of PTP1B in cell cultures decreases insulin-stimulated phosphorylaton of IR and/or IRS-1, whereas a reduction in the level of PTP1B augments insulin-initiated signaling ${ }^{[6]}$. The genetic analysis of the PTPN1 gene, coding for PTP1B in humans, revealed a significant association with metabolic traits consistent with the proposed in vivo role of PTP1B ${ }^{[22]}$. In murine models, disruption of the PTPN1 gene resulted in resistance to diet-induced obesity and increased insulin sensitivity. The $P T P 1 B^{-} /^{-}$mice had significantly lower triglyceride levels even at feeding on a high-fat diet, and showed an enhanced response toward leptin-mediated weight loss and suppression of feeding ${ }^{[23-25]}$. In addition, small molecule PTP1B inhibitors can act as both insulin mimetics and insulin sensitizers ${ }^{[26]}$. Consequently, it has been suggested that the PTP1B inhibitors might have a role in the treatment of type 2 diabetes and obesity.

\section{Natural PTP1B inhibitors Phenolics}

Phenolics are characterized by having at least one aromatic ring with one or more hydroxyl groups attached ${ }^{[27]}$. According to their structural characteristics, the phenolics discussed below are classified into seven groups, including flavonoids, bromophenol, phenolic acid, phenolics containing furan or pyran rings, coumarins, lignans and miscellaneous phenolics.

\section{Flavonoids}

Flavonoids are polyphenolic compounds comprised of 15 carbons, with two aromatic rings connected by a three-carbon bridge. They are the most numerous natural products and exist extensively in nature. Flavonoids include flavonols, flavones, flavanones, isoflavones, catechins, anthocyanidins and chalcones. Their potential beneficial effects, such as antiviral, antitumor, antiplatelet, anti-inflammatory and antioxidant activities, greatly interest chemists and pharmacologists. For example, just between January 2007 and December 2009, 796 new naturally occurring flavonoids were isolated from various natural resources ${ }^{[28]}$.

In 2002, five natural flavonoids, including 8-(1,1-dimethylallyl)-5'-(3-methylbut-2-enyl)-3', ' $^{\prime}, 5,7$-tetrahydroxyflanvonol 1, 3'-(3-methylbut-2-enyl)-3', ' $^{\prime}, 7$-trihydroxyflavane 2 , quercetin 3 , uralenol 4, and broussochalcone A 5 were isolated from the roots of the plant Broussonetia papyrifera collected from Zhibo, Anhui province, China ${ }^{[17]}$. Flavonoids 1-5 showed inhibitory activity against PTP1B with $\mathrm{IC}_{50}$ values ranging from 4.3 to $36.8 \mu \mathrm{mol} / \mathrm{L}$. The preliminary SAR study indicated that less polar substituents at the 3', 4',5,7-tetrahydroxyflanvonol skeleton produced stronger inhibitory activities.

Licochalcones A 6, C 7, and E 8 were isolated from the $\mathrm{CH}_{2} \mathrm{Cl}_{2}$ extract of plant Glycyrrhiza inflate ${ }^{[29]}$. Evaluation of the inhibitory activity of licochalcones 6-8, together with their 4- and/or 4'-hydroxyl group methylated and/or acetylated derivatives indicated that the presence of the allyl group in ring $B$ might increase inhibitory activity. However, the degree of activation varied depending on the configuration and substitution position of the allyl group in ring $B$ and the inhibitory 
activity was strongest when $4^{\prime}$-hydroxyl group in $\mathbf{6}$ was methylated. Licochalcone A 6 was concisely synthesized through water-accelerated [3,3]-sigmatropic rearrangement of an aryl isoprenyl ether as a key step ${ }^{[30]}$. Licochalcones C 7 was synthesized by a simple, inexpensive high yield method starting from 3-(3-methyl-2-butenyl)-2,4-dihydroxybenzaldehyde ${ }^{[31]}$. Licochalcone E $\mathbf{8}$ was first synthesized by employing Claisen rearrangement for synthesis of the key intermediate ${ }^{[32]}$.

Three PTP1B inhibitors, glycyrrhisoflavone 9, glisoflavone 10, and licoflavone A 11, were isolated from the roots of plant $G_{\text {uralensis }^{[33]}}$. Of these isolates, glisoflavone $\mathbf{1 0}$ showed the strongest inhibitory activity with an $\mathrm{IC}_{50}$ of $27.9 \mu \mathrm{mol} / \mathrm{L}$, and kinetic analysis indicated that it inhibited PTP1B in a mixedtype manner. The presence of an isoprenyl group and an ortho-hydroxyl group was considered to be important for exhibiting the activity.

Bioassay-guided fractionation of the $\mathrm{CHCl}_{3}$-soluble fraction of plant Morus bombycis led to the isolation of three chalcone-derived Diels-Alder products: kuwanons J 12, R 13, and $\mathrm{V} \mathrm{14}{ }^{[34]}$. All of these kuwanons showed remarkable inhibitory activity with $\mathrm{IC}_{50}$ values ranging from 4.3 to 13.8 $\mu \mathrm{mol} / \mathrm{L}$. The order of inhibitory activity of kuwanons was 12>13>14, suggesting that increasing the number of hydroxyl groups improved the inhibitory effect. Additionally, a kinetics analysis suggested that these kuwanons inhibited PTP1B in a mixed-type manner, indicating that they might displace at both the active site and an additional binding site of the PTP1B.

The plant Cyclocarya paliurus has been used as a traditional tonic, and its leaves have been processed as tea products. Quercetin-3-O- $\beta$-D-glucuronide 15 and myricetin-3-O- $\beta-D$ glucuronide 16 were isolated from the leaves of $C$ paliurus ${ }^{[35]}$. Compound $16\left(\mathrm{IC}_{50}=9.47 \pm 3.31 \mu \mathrm{g} / \mathrm{mL}\right)$ was slightly less active than $15\left(\mathrm{IC}_{50}=7.39 \pm 1.15 \mu \mathrm{g} / \mathrm{mL}\right)$, indicating that the decrease in activity is attributed to the addition of one hydroxyl group to $\mathrm{C}^{-5} 5^{\prime}$ in ring $\mathrm{B}$. As an epimer of 15 , quercetin-3-O-a-Dglucuronide was inactive, implying that sugar configuration played a key role in in vitro inhibitory activity. The synthesis of 15 was achieved in 1970 by coupling 7,4'-dibenzylquercetin with methyl(tri-O-acetyl-a- $D$-glucopyranosyl bromide)uronate followed by total acetylation of the product and subsequent removal of the protecting groups ${ }^{[36]}$.

The herb Scutellaria indica, known as 'Han-Xin-Cao' distributed widely in Asia, is traditionally used for hemoptysis, hematemesis, antitumor activity, and the treatment of other diseases in China. From the extract of $S$ indica, wogonin $\mathbf{1 7}$ and (2S)-5,7-dihydroxy-8,2'-dimethoxyflavanone 18 were isolated with weak inhibitory activity ${ }^{[37]}$. In 2003, Huang et al synthesized 17 in 3 steps by a concise and efficient method ${ }^{[38]}$.

Flavonoids 19-23 were isolated from an EtOAc-soluble partition of the $\mathrm{MeOH}$ extract of the plant Tetracera scandens, a traditional Vietnamese medicinal plant showing some therapeutic activities in inflammation, hepatitis and gout ${ }^{[39]}$. Flavonoids 19, 21-23 exhibited stronger inhibitory activity $\left(\mathrm{IC}_{50}\right.$ values ranging from $20.63 \pm 0.17$ to $37.52 \pm 0.31 \mu \mathrm{mol} / \mathrm{L})$ than 20 $\left(\mathrm{IC}_{50}>80 \mu \mathrm{mol} / \mathrm{L}\right)$. Moreover, compounds 19 and 21-23 exhib- ited significant glucose-uptake activity in basal and insulinstimulated L6 myotubes, stimulated AMPK, phosphorylation, and inhibited GLUT4 and GLUT1 mRNA expressions. Furthermore, compounds 19, 22, and 23 showed no muscle cell toxicity at levels up to $60 \mu \mathrm{mol} / \mathrm{L}$, indicating that they could be possible lead candidates for the treatment of type 2 diabetes. Compound 23 had been synthesized by Rao et al in 1987 ${ }^{[40]}$ (Figure 1).

From fruits of the plant Pongamia pinnata, the flowers of which were found to have anti-hyperglycemic and antilipidperoxidative activities $^{[41]}$, pongamol 24 and karanjin 25 were obtained. Both flavonoids exhibited inhibitory activity with $\mathrm{IC}_{50}$ values of $75.0 \mu \mathrm{mol} / \mathrm{L}$ and $84.5 \mu \mathrm{mol} / \mathrm{L}$, and with $K_{\mathrm{i}}$ values of $58 \mu \mathrm{mol} / \mathrm{L}$ and $76 \mu \mathrm{mol} / \mathrm{L}$, respectively ${ }^{[42]}$. In Streptozotocin (STZ)-induced diabetic rats, single-dose treatment with 24 and 25 lowered the blood glucose level by $12.8 \%$ $(P<0.05)$ and $11.7 \%(P<0.05)$ at a $50 \mathrm{mg} / \mathrm{kg}$ dose and $22.0 \%$ $(P<0.01)$ and $20.7 \%(P<0.01)$ at a $100 \mathrm{mg} / \mathrm{kg}$ dose, respectively, $6 \mathrm{~h}$ post-oral administration. Additionally, they significantly lowered the blood glucose level in $\mathrm{db} / \mathrm{db}$ mice, which is well characterized as a mode of type 2 diabetes, with percent activities of $35.7 \%(P<0.01)$ and $30.6 \%(P<0.01)$, respectively, at a 100 $\mathrm{mg} / \mathrm{kg}$ dose after consecutive treatment for $10 \mathrm{~d}$. Therefore, the anti-hyperglycemic activity of $P$ pinnata for STZ-induced diabetic rats and type 2 diabetic $\mathrm{db} / \mathrm{db}$ mice is likely due to the PTP1B inhibitory effect of $\mathbf{2 4}$ and 25. Pongamol 24 was synthesized by Goel et al in 2004 and Yadav et al in 2005 ${ }^{[43,44]}$. Karanjin 25 was synthesized by Hossain et al in $2003^{[45]}$.

The plants in genus Erythrina of the Leguminosae family are distributed in tropical and subtropical zones of the world and have been used to treat many ailments. During a study to search for PTP1B inhibitors, Oh et al isolated and characterized a series of flavonoids (26-114) described below from the extract of the species Erythrina. Most of the flavonoids isolated showed significant inhibitory activity against PTP1B ${ }^{[46-54]}$.

Six prenylated isoflavonoids 26-31 were isolated from the EtOAc extract of the stem bark of $E$ addisoniae ${ }^{[46]}$. The bioassay results indicated that $30\left(\mathrm{IC}_{50}=2.6 \pm 0.5 \mu \mathrm{mol} / \mathrm{L}\right)$ and 31 $\left(\mathrm{IC}_{50}=4.1 \pm 0.2 \mu \mathrm{mol} / \mathrm{L}\right)$, both bearing an isoprenyl group and a dimethylpyran moiety in the ring $\mathrm{A}$, exhibited stronger inhibitory activity than $26\left(\mathrm{IC}_{50}=10.1 \pm 0.3 \mu \mathrm{mol} / \mathrm{L}\right)$, suggesting that cyclization between a hydroxy group at C-7 and one of the isoprenyl groups at C-6 or C-8 in ring A may be important for activity. Moreover, the $2^{\prime}, 4^{\prime}$-dihydroxy group in ring $\mathrm{B}$ of isoflavanoids appears to correlate with the inhibitory activity, and a double bond between C-2 and C-3 of the ring might be responsible for a loss of activity.

Bioassay-guided fractionation of an EtOAc-soluble extract of the root bark of E mildbraedii yielded flavonoids 19 and 32-39, which show significant inhibitory activity $\left(\mathrm{IC}_{50}\right.$ ranging from $14.8 \pm 1.1$ to $39.7 \pm 2.5 \mu \mathrm{mol} / \mathrm{L})^{[47]}$. Flavonoid $35\left(\mathrm{IC}_{50}=39.7 \pm 2.5\right.$ $\mu \mathrm{mol} / \mathrm{L})$, with one more hydroxyl group at C-5, was less active than 36. A similar observation was made for flavonoids 32 and 33, indicating that addition of a hydroxyl group to C-5 in ring A may be responsible for the loss of in vitro activity. Flavonoid $34\left(\mathrm{IC}_{50}>60 \mu \mathrm{mol} / \mathrm{L}\right)$, in which an additional 
nog

www.nature.com/aps

Jiang CS et al

1220<smiles>C=CC(C)(C)c1c(O)cc(O)c2c(=O)c(O)c(-c3cc(O)c(O)c(CC=C(C)C)c3)oc12</smiles>

1<smiles>C=CC(C)(C)c1cc(/C=C/C(=O)c2ccc(O)cc2)c(OC)cc1O</smiles>

6<smiles>[H][R9]([H])([H])[C@@H](O)c1cc(O)cc2occ(-c3cc(O)c(O)c(CC=C(C)C)c3)c(=O)c12</smiles><smiles>[R]c1cc(-c2oc3cc(O)cc(O)c3c(=O)c2[R])cc(O)c1O</smiles>

$15 R_{1}=H, R_{2}=3-O-\beta-D$-glucuronic acid $16 \mathrm{R}_{1}=\mathrm{OH}, \mathrm{R}_{2}=3-O-\beta-D$-glucuronic acid<smiles>CC(C)=CCc1cc(C2CCc3ccc(O)cc3O2)cc(O)c1O</smiles>

2<smiles>COc1c(/C=C/C(=O)c2ccc(O)cc2)ccc(O)c1CC=C(C)C</smiles>

7<smiles>CC(C)=CCc1cc2c(=O)cc(-c3ccc(O)cc3)oc2cc1O</smiles>

11<smiles>[R]c1cc(-c2oc3cc(O)cc(O)c3c(=O)c2O)cc(O)c1O</smiles>

$3 \mathrm{R}=\mathrm{H}$

$4 \mathrm{R}=$ isoprenyl<smiles>CC(C)=CCc1cc(C(=O)/C=C/c2ccc(O)c(O)c2)c(O)cc1O</smiles>

5

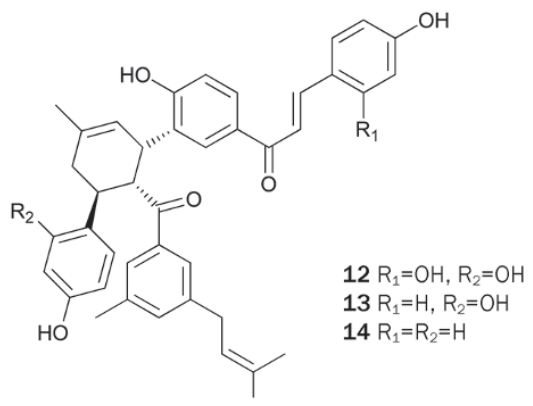<smiles>O=c1c(-c2ccc(O)cc2)coc2cc(O)cc(O)c12</smiles>

20<smiles>COc1c(C(=O)/C=C(\O)c2ccccc2)ccc2occc12</smiles>

24<smiles>CC(C)=CCc1cc(-c2coc3cc(O)cc(O)c3c2=O)cc(CC=C(C)C)c1O</smiles>

21<smiles>COc1c(-c2ccccc2)oc2c(ccc3occc32)c1=O</smiles>

25<smiles>COc1cc(O)c2c(c1OC)O[C@@H](c1cc(O)ccc1O)CC2=O</smiles>

18<smiles>CC(C)=CCc1c(O)c(CC=C(C)C)c2occ(-c3ccc(O)cc3)c(=O)c2c1O</smiles>

22<smiles>CC(C)=CCc1c(O)c(CC=C(C)C)c2c(c1O)C(=O)C(c1ccc(O)cc1O)CO2</smiles>

26<smiles>CC1(C)C=Cc2c(cc3occ(-c4ccc(O)cc4)c(=O)c3c2O)O1</smiles>

19<smiles>CC1(C)C=Cc2c(cc(O)c3c(=O)c(-c4ccc(O)cc4)coc23)O1</smiles>

23<smiles>CC(C)=CCc1c2c(c3occ(-c4ccc(O)cc4)c(=O)c3c1O)CC(C(C)(C)O)O2</smiles>

27

Figure 1. Structures of flavonoids 1-27.

hydroxyl group is present at C-3" of the isoprenyl group, exhibited a significantly lower inhibitory activity than 33 . The inhibitory activity of $\mathbf{3 8}$ was similar to that of $\mathbf{3 5}$, suggesting that cyclization between a hydroxyl group and one of the isoprenyl groups in ring B may not affect the resultant activeity. A group of related flavonoids, commercially available or isolated from other plants ${ }^{[55]}$, was assayed to evaluate the role of the isoprenyl group in ring B in the bioactivity. The

Acta Pharmacologica Sinica 
results indicated that substitution of isoprenyl groups in the ring B might be important for inhibitory activity in vitro, and introduction of one more hydroxyl group to $\mathrm{C}-5$ of ring $\mathrm{A}$ or one of the isoprenyl groups in ring B may be responsible for the loss of activity. Likewise, the presence of isoprenyl groups in ring $\mathrm{A}$ seems to be essential for the activity of chalcones ${ }^{[47]}$. Further studies on the EtOAc-soluble extract of the root bark

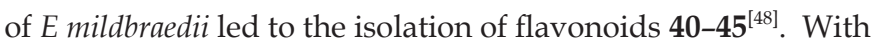
the exception of $\mathbf{4 3}$, which has an isoprenyl group in ring $\mathrm{A}$, the other flavonoids inhibited PTP1B in vitro with $\mathrm{IC}_{50}$ values ranging from $5.5 \pm 0.3$ to $42.6 \pm 2.4 \mu \mathrm{mol} / \mathrm{L}$, thus demonstrating that the isoprenyl group in the ring B played an important role in suppressing PTP1B. Recently, flavonoid 33 was synthesized as an inhibitor of prostate cancer and MMP-2 expression ${ }^{[56]}$. The first synthesis of other flavonoids, such as $35,39,40$, and 45, has also been reported ${ }^{[40,57-59]}$ (Figure 2).

Abyssinoflavanones V-VII 46-48, together with sigmoidins A-C 49-51, F 52, abyssinins I 53, II 44, 5-deoxyabyssinin II 54, 3'-prenylnarringenin 55, abyssinone-VI 56, licoagrochalcone A $57^{[49]}$, flavonoids $58-73^{[50]}$, flavanones $74-79$ with a dihydrofuran moiety, erylatissin C $\mathbf{8 0}$, abyssinin III $\mathbf{8 1} \mathbf{1}^{[51]}$, and flavanones $82-93^{[52]}$ were isolated from the stem bark of $E$ abyssinica. Among the isolates $46-57$, compounds $47-50$ and $52-57$ strongly inhibited PTP1B in in vitro assays with $\mathrm{IC}_{50}$ values ranging from $14.2 \pm 1.7$ to $26.7 \pm 1.2 \mu \mathrm{mol} / \mathrm{L}$. Flavonoids 58, 60, 62, 63, 65, and 66 exhibited inhibitory effects on PTP1B in in

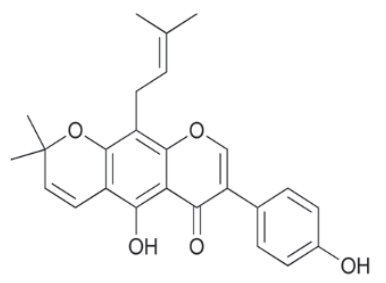

28<smiles>[R7]Oc1c(CC=C(C)C)cc([C@H]2CC(=O)c3c([R20])cc(O)cc3O2)cc1CC=C(C)C</smiles><smiles>COc1cc(OC)c2c(=O)c(-c3ccc(O)cc3)coc2c1</smiles>

39

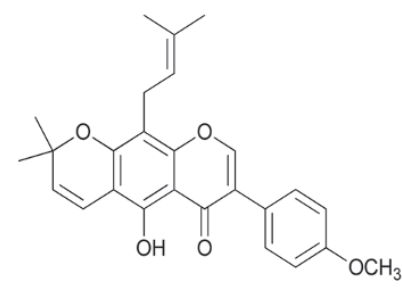

29<smiles>COc1c(/C=C/C(C)(C)O)cc([C@H]2CC(=O)c3ccc(O)cc3O2)cc1CC=C(C)C</smiles><smiles>COc1ccc([C@@H]2CC(=O)c3c(O)cc(O)cc3O2)cc1CC=C(C)C</smiles>

vitro assays with $\mathrm{IC}_{50}$ values ranging from $13.9 \pm 2.1$ to $19.0 \pm 1.8$ $\mathrm{mmol} / \mathrm{L}$. Additionally, compounds 59, 61, 64, and 67-71 with 2,2-dimethylpyrano ring(s), in which isoprenyl and/or methoxyl groups are absent, showed very weak inhibitory effects. Flavonoids 74, 75, 77, and 79-81 inhibited PTP1B in a dosedependent manner, with $\mathrm{IC}_{50}$ values ranging from 15.2 \pm 1.2 to $19.6 \pm 2.3 \mu \mathrm{mol} / \mathrm{L}$. Flavonoids 74 and 77 with the isoprenyl group at C-3', and 75 with methoxyl group at C-3' exhibited stronger inhibitory activity $\left(\mathrm{IC}_{50} 15.2 \pm 1.2,17.9 \pm 2.6 \mu \mathrm{mol} / \mathrm{L}\right.$, respectively) than 76 and $78\left(\mathrm{IC}_{50}>60 \mu \mathrm{mol} / \mathrm{L}\right.$, respectively) without an isoprenyl or a methoxyl group. Among flavonoids 82-93, most flavanones exhibited potent inhibitory effects on PTP1B ( $\mathrm{IC}_{50}$ ranging from 14.9 to $35.8 \mu \mathrm{mol} / \mathrm{L}$ ) except for 83, 86, 90, and $92\left(\mathrm{IC}_{50}>72 \mu \mathrm{mol} / \mathrm{L}\right)$. All of these results indicated that the significant inhibitory activity of these flavonoids could be attributed to the isoprenyl or methoxyl groups in the ring $\mathrm{B}$, while the presence of a polar functionality (eg, hydroxyl group) caused the activity to decrease. However, the 2,2-dimethylpyrano or dihydrofurano residue was considered to have almost no effect on the inhibitory activity when the isoprenyl or methoxy groups exist in the ring $\mathrm{B}$. Treatment of $\mathrm{CHO} / \mathrm{hIR}$ cells with 75 resulted in a time-dependent increase of the insulin-induced tyrosine phosphorylation of IR and IRS, and cytotoxicity was not observed in cells treated with over $20 \mu \mathrm{mol} / \mathrm{L}$ of 75 for $48 \mathrm{~h}$. These results indicated that 75 might also act in the cells as an insulin-sensitizing agent. Given that those

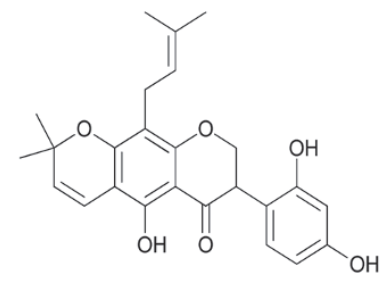

30<smiles>COc1c(CC=C(C)C)cc(/C=C/C(=O)c2ccc(O)cc2O)cc1CC=C(C)C</smiles><smiles>COc1cc(O)c(-c2coc3cc(O)ccc3c2=O)cc1CC=C(C)C</smiles>
41

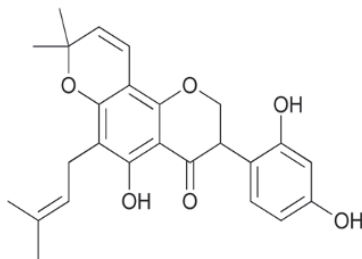

31<smiles>CC(C)=CCc1cc([C@H]2CC(=O)c3c(O)cc(O)cc3O2)cc2c1OC(C)(C)C=C2</smiles><smiles>CC(C)=CCc1c(O)c([C@H]2COc3cc(O)ccc3C2)cc2c1OC(C)(C)C=C2</smiles>

Figure 2. Structures of flavonoids 28-42. 
flavonoids showed promising bioactivity, some have been synthesized. The complete synthesis of $\mathbf{4 6}$ was first achieved through C-prenylation, selective protection of the phenolic hydroxyl group, aldol condensation, cyclization and deprotection starting from the inexpensive materials 4-hydroxybenzaldehyde and 2,4,6-trihydroxyacetophenone with a total yield of $24 \%{ }^{[60]}$. Rao et al prepared 83 by condensing 2,2-dimethyl chrom-3-6-carboxaldehyde with protected resacetophenone under phase transfer conditions followed by deprotection and cyclization $^{[61]}$. In 2006, abyssinone II 84 was synthesized via condensation of the aldehyde with an $o$-hydroxyacetophenone under Claisen-Schmidt conditions followed by cyclization and deprotection $^{[62]}$. Using a synthetic procedure similar to the one described above, Maiti et al synthesized $\mathbf{8 7}$, an analog of $\mathbf{8 4}^{[63]}$ (Figure 3).

Bioassay-guided fractionation of the EtOAc extract of the stem bark of $E$ abyssinica resulted in the isolation of nine pterocarpan derivatives $\mathbf{9 4 - 1 0 2}$, which showed inhibitory activity ${ }^{[53]}$. Compounds 94, 96, 98, 99, and 101 exhibited inhibitory activity with $\mathrm{IC}_{50}$ values ranging from $4.2 \pm 0.2$ to $19.3 \pm 0.3 \mu \mathrm{mol} / \mathrm{L}$, and showed strong cytotoxic activities against MCF7, MCF7/ TAMR, MCF7/ADR and MDA-MB-231 breast cancer cell lines with $\mathrm{IC}_{50}$ values from $5.6 \pm 0.7$ to $28.0 \pm 0.2 \mu \mathrm{mol} / \mathrm{L}$. Additionally, the other pterocarpan derivatives were weakly active or not active against PTP1B and cancer cell lines. Thus, the antitumor activity of $\mathbf{9 4}, \mathbf{9 6}, \mathbf{9 8}, \mathbf{9 9}$, and 101 was possibly attributed to their PTP1B inhibitory effects. From the MeOH extract of the stem bark of Elysistemon, other pterocarpan derivatives 103-114 were isolated ${ }^{[54]}$. All of the isolates, with the exception of 105,108 , and 113 , inhibited PTP1B activity with $\mathrm{IC}_{50}$ values ranging from $1.01 \pm 0.3$ to $18.1 \pm 0.9 \mu \mathrm{g} / \mathrm{mL}$. The diisoprenylated $114\left(\mathrm{IC}_{50}=1.01 \pm 0.3 \mu \mathrm{g} / \mathrm{mL}\right)$ had the strongest activity. Compounds 104, 111, 112, and 114 were highly active compared to the weak 103, 106, and 107 compounds, which only have a pyran ring. These results suggested that isoprenylation of ring $\mathrm{A}$ and/or ring D played an important role in PTP1B inhibitory properties. Phaseollin $\mathbf{1 0 7}$ was synthesized by Mohamed et al in $1987^{[64]}$ (Figure 4).

From the MeOH extract of plant Selaginella tamariscina, used to treat infectious disease and malignant tumors, amentoflavone $\mathbf{1 1 5}$ was obtained and characterized as a noncompetitive PTP1B inhibitor $\left(\mathrm{IC}_{50}\right.$ value of $7.3 \pm 0.5 \mu \mathrm{mol} / \mathrm{L}$ and $K_{\mathrm{i}}$ value of $\left.5.2 \mu \mathrm{mol} / \mathrm{L}\right)^{[65]}$. Treatment with $\mathbf{1 1 5}$ of 32D cells overexpressing the IR resulted in a dose-dependent increase in tyrosine phosphorylation of IR, possibly through inhibition of PTP1B to enhance insulin-induced intracellular signaling.

The leaf of Morus sp has been used in traditional Chinese medicinal to treat diabetes mellitus, and 'Sang-Bai-Pi', the root bark of the same plant, is also well known as a Chinese crude drug. From the extract of 'Sang-Bai-Pi', sanggenons C 116, G 117, and kuwanon L 118 were isolated ${ }^{[66]}$. Compounds 116-118 inhibited PTP1B $\left(\mathrm{IC}_{50}\right.$ values ranging from $1.6 \pm 0.3$ to $16.9 \pm 1.1$ $\mu \mathrm{mol} / \mathrm{L})$ with good selectivity over other PPs, expecially 116 and 118, which showed no inhibitory effects toward VHR and PP1 at levels up to $50 \mu \mathrm{mol} / \mathrm{L}$. In addition, sanggenons $\mathbf{1 1 6}$ and 117 inhibited PTP1B in the mixed-type manner (Figure 5).

\section{Bromophenols}

The marine environment is a rich source of bromophenols, which exhibit interesting and useful biological activities, including feeding deterrent, antimicrobial, and radical-scavenging activities ${ }^{[67]}$. Several species of marine algae are found to contain bromophenols with PTP1B inhibitory activity.

Bromophenol 119, isolated from the red alga Polysiphonia urceolata collected at the coast of Weihai, China, showed potent inhibition against PTP1B with an $\mathrm{IC}_{50}$ value of $4.9 \mu \mathrm{g} / \mathrm{mL}^{[68]}$.

Isolation of the ethanol extract from the red alga Rhodomela confervoides collected at the coast of Qingdao, China, which displayed anti-hyperglycemic effects of on STZ-induced diabetes in male Wistar rats fed with high fat diet, produced four bromophenols 120-123. All four bromophenols 120-123 showed significant inhibitory activity with $\mathrm{IC}_{50}$ values ranging from 0.84 to $2.4 \mu \mathrm{mol} / \mathrm{L}$, which might be responsible for the in vivo anti-hyperglycemic activity of the extract ${ }^{[69]}$. Bromophenols 124-126, isolated from algae $R$ confervoides collected at the coast of Qingdao, China, and Leathesia nan collected at the coast of Weihai, China, showed significant inhibitory activity with $\mathrm{IC}_{50}$ values ranging from 2.8 to $4.5 \mu \mathrm{mol} / \mathrm{L}^{[70]}$. Additional studies on chemical constituents of $R$ confervoides and $P$ urceolata produced two more PTP1B inhibitors with bromophenol structures 127 and $\mathbf{1 2 8} 8^{[67]}$. Bromophenol 120 was synthesized in four steps with an overall yield of $14.7 \%^{[71]}$. Bromophenol 122 and its related analogs were synthesized to test for their antifungal activity ${ }^{[72]}$. Bromophenols 123, 127 and 128 were synthesized in eight steps with overall yields of $14.4 \%, 14.4 \%$, and $18.2 \%$, respectively, via a practical approach using bromination, Wolff-Kishner-Huang reduction and a Friedel-Crafts reaction as key steps ${ }^{[67]}$. Bromophenol 123 exhibited better inhibitory activity than $\mathbf{1 2 7}$ and $\mathbf{1 2 8}$, suggesting that the long side chain at the $R_{1}$ position and the bromine atom at the $R_{2}$ position enhanced the biological inhibitory activity.

Bromophenols 129 and 130, isolated from the Hainan red alga Laurencia similis, showed strong inhibitory activity with $\mathrm{IC}_{50}$ of 2.97 and $2.66 \mu \mathrm{mol} / \mathrm{L}$, respectively ${ }^{[73]}$. Bromophenols 131-135, together with 124, were isolated from the red alga Symphyocladia latiuscula, collected from the Weihai coastline of Shandong Province. Bromophenols 132-134 showed potent activity with $\mathrm{IC}_{50}$ values of $3.9,4.3$, and $3.5 \mu \mathrm{mol} / \mathrm{L}$, respectively ${ }^{[74]}$. The first synthesis of $\mathbf{1 3 3}$ was reported by Balaydin et al $^{[75]}$ (Figure 6).

\section{Phenolic acids}

Caffeic acid $\mathbf{1 3 6}$ is a widespread phenolic acid that occurs naturally in many agriculture products such as fruits, vegetables, wine, olive oil, and coffee ${ }^{[7]}$. Isolated from the aerial parts of Artemisia minor, phenolic acid $\mathbf{1 3 6}$ was found to be a PTP1B inhibitor with an $\mathrm{IC}_{50}$ value of $3.06 \mu \mathrm{mol} / \mathrm{L}^{[77]}$. Together with 136, another three phenolic acids $137^{[35]}, 138$ and $139^{[78]}$ were isolated from the leaves of the plant Cyclocarya paliurus and the fruiting body of the fungus Phellinus linteus, respectively. Compounds 137-139 had inhibitory activity with $\mathrm{IC}_{50}$ values of $16.64 \pm 0.04^{[35]}, 52.9 \pm 3.6$ and $26.2 \pm 1.9 \mu \mathrm{mol} / \mathrm{L}^{[78]}$, respectively. 2-Acetylaminogentisic acid 140, isolated from fungus Strepto- 
<smiles>CC(C)=CCc1c(O)cc2occ(-c3ccc(O)cc3)c(=O)c2c1O</smiles>

43<smiles>CC(C)=CCc1cc([C@H]2CC(=O)c3c(O)cc(O)cc3O2)cc2ccoc12</smiles>

47<smiles>CC(C)=CCc1c([C@H]2CC(=O)c3c(O)cc(O)cc3O2)cc2c(c1O)OC(C)(C)C=C2</smiles>

52<smiles>CC1(C)C=Cc2cc([C@H]3CC(=O)c4c(O)cc(O)cc4O3)c3c(c2O1)OC(C)(C)C=C3</smiles>

61<smiles>[R]c1cc(O)cc2c1C(=O)C[C@@H](c1cc3c(c([R])c1[R])OC(C)(C)C([R])C3[R])O2</smiles>

$62 R_{1}=R_{5}=O H, R_{2}=R_{4}=H, R_{3}=$ isoprenyl $63 \mathrm{R}_{1}=\mathrm{R}_{5}=\mathrm{OH}, \mathrm{R}_{2}=\mathrm{R}_{4}=\mathrm{H}, \mathrm{R}_{3}=\mathrm{OCH}_{3}$ $64 R_{1}=R_{4}=R_{5}=O H, R_{2}=R_{3}=H$ $65 \mathrm{R}_{1}=\mathrm{R}_{4}=\mathrm{R}_{5}=\mathrm{OH}, \mathrm{R}_{2}=\mathrm{H}, \mathrm{R}_{3}=$ isoprenyl $66 \mathrm{R}_{1}=\mathrm{R}_{4}=\mathrm{R}_{5}=\mathrm{OH}, \mathrm{R}_{2}=$ isoprenyl, $\mathrm{R}_{3}=\mathrm{H}$ $67 \mathrm{R}_{1}=\mathrm{R}_{3}=\mathrm{OH}, \mathrm{R}_{2}=\mathrm{R}_{5}=\mathrm{H}, \mathrm{R}_{4}=(=0)$ $68 \mathrm{R}_{1}=\mathrm{R}_{2}=\mathrm{R}_{4}=\mathrm{H}, \mathrm{R}_{3}=\mathrm{R}_{5}=\mathrm{OH}$

$69 \mathrm{R}_{1}=\mathrm{R}_{2}=\mathrm{H}, \mathrm{R}_{3}=\mathrm{R}_{4}=\mathrm{R}_{5}=\mathrm{OH}$ $71 R_{1}=R_{3}=R_{4}=R_{5}=O H, R_{2}=H$<smiles>COc1cc([C@H]2CC(=O)c3c(O)cc(O)cc3O2)cc(CC=C(C)C)c1O</smiles>

44<smiles>C=C(C)[C@H](O)Cc1cc([C@H]2CC(=O)c3c(O)cc(O)cc3O2)cc(CC=C(C)C)c1O</smiles>

48<smiles>COc1cc([C@H]2CC(=O)c3ccc(O)cc3O2)cc(CC=C(C)C)c1O</smiles>

54<smiles>CC1(C)Oc2c(O)cc([C@H]3CC(=O)c4c(O)cc(O)cc4O3)cc2C[C@H]1O</smiles>

70<smiles>[R]C1c2cc([C@@H]3CC(=O)c4c(O)cc(O)cc4O3)cc(CC=C(C)C)c2O[C@H]1C(C)(C)O</smiles><smiles>CC1(C)C=Cc2c(cc3occ(-c4ccc(O)cc4O)c(=O)c3c2O)O1</smiles>

45<smiles>CC(C)=CCc1cc([C@H]2CC(O)c3c(O)cc(O)cc3O2)c(CC=C(C)C)c(O)c1O</smiles>

49<smiles>[R]c1cc(/C=C/C(=O)c2ccc(O)cc2O)cc(CC=C(C)C)c1O</smiles>

$57 \mathrm{R}=\mathrm{H}$<smiles>COc1c(/C=C/C(C)(C)O)cc([C@H]2CC(=O)c3c(O)cc(O)cc3O2)cc1CC=C(C)C</smiles>

72<smiles>[R2]c1cc([C@H]2CC(=O)c3c(O)cc(O)cc3O2)cc2c1O[C@H](C(C)(C)O)C2[R]</smiles>

$75 \mathrm{R}_{1}=\mathrm{H}, \mathrm{R}_{2}=\mathrm{OCH}_{3}$

$76 \mathrm{R}_{1}=\mathrm{H}, \mathrm{R}_{2}=\mathrm{OH}$ $78 \mathrm{R}_{1}=\mathrm{OH}, \mathrm{R}_{2}=\mathrm{OH}$<smiles>[R]c1cc([C@H]2CC(=O)c3c(O)cc(O)cc3O2)cc2c1OC(C)(C)C=C2</smiles><smiles>[R]c1cc([C@H]2CC(=O)c3c(O)cc(O)cc3O2)cc(CC=C(C)C)c1O</smiles><smiles>[R]c1cc([C@H]2CC(=O)c3c(O)cc(O)cc3O2)c([R])c2c1OC([R3])(C)C=C2</smiles>

$58 \mathrm{R}_{1}=$ isoprenyl, $\mathrm{R}_{2}=\mathrm{OH}, \mathrm{R}_{3}=\mathrm{CH}_{3}$ $59 \mathrm{R}_{1}=\mathrm{H}, \mathrm{R}_{2}=\mathrm{OH}, \mathrm{R}_{3}=\mathrm{CH}_{2} \mathrm{OH}$ $60 \mathrm{R}_{1}=\mathrm{H}, \mathrm{R}_{2}=\mathrm{OCH}_{3}, \mathrm{R}_{3}=\mathrm{CH}_{2} \mathrm{OH}$<smiles>C=C(C)/C=C/c1cc([C@H]2CC(=O)c3c(O)cc(O)cc3O2)cc(CC=C(C)C)c1OC</smiles>

73<smiles>CC(C)=CCc1c([C@H]2CC(=O)c3c(O)cc(O)cc3O2)cc2c(c1C)O[C@H](C(C)(C)O)[C@H]2O</smiles>

79

Figure 3. Structures of flavonoids 43-79. 
<smiles>[R]c1cc([C@@H]2CC(=O)c3c([R])cc(O)cc3O2)cc([R])c1[R]</smiles>

$80 R_{1}=R_{2}=H, R_{3}=O H, R_{4}=O C_{3}, R_{5}=$ isoprenyl $81 R_{1}=R_{4}=R_{5}=O H, R_{2}=R_{3}=$ isoprenyl<smiles>[R]Oc1c([R])cc(C2CC(=O)c3ccc(O)cc3O2)cc1[R]</smiles>

$84 \mathrm{R}_{1}=\mathrm{H}, \mathrm{R}_{2}=\mathrm{CH}_{3}, \mathrm{R}_{3}=$ isoprenyl $86 \mathrm{R}_{1}=\mathrm{R}_{2}=\mathrm{H}, \mathrm{R}_{3}=\mathrm{CHO}$

$87 \mathrm{R}_{1}=\mathrm{R}_{2}=H, \mathrm{R}_{3}=$ isoprenyl $90 R_{1}=R_{2}=R_{3}=H$

$91 \mathrm{R}_{1}=\mathrm{R}_{2}=\mathrm{H}, \mathrm{R}_{3}=\mathrm{OCH}_{3}$

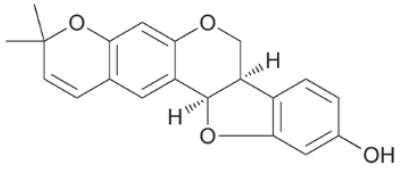

95

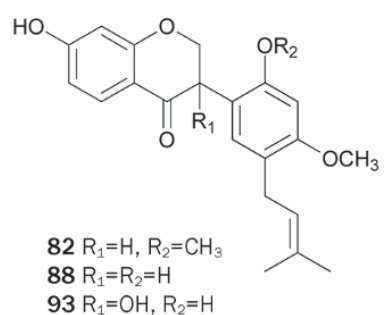

$93 \mathrm{R}_{1}=\mathrm{OH}, \mathrm{R}_{2}=\mathrm{H}$
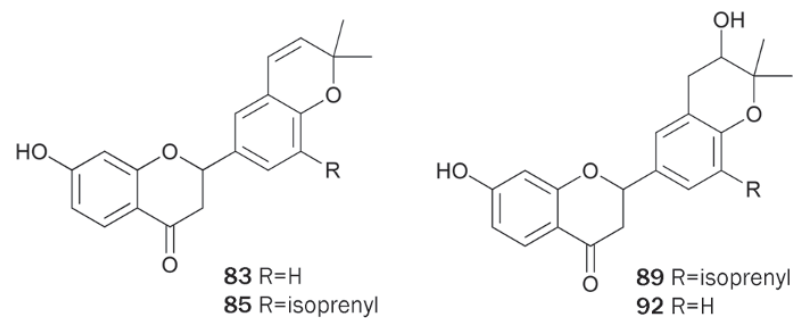

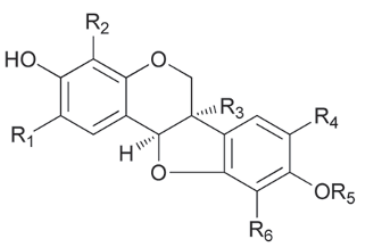

$94 \mathrm{R}_{1}=\mathrm{R}_{2}=\mathrm{R}_{4}=\mathrm{H}, \mathrm{R}_{3}=\mathrm{OCH}_{3}, \mathrm{R}_{5}=\mathrm{CH}_{3}, \mathrm{R}_{6}=$ isoprenyl

$97 R_{1}=R_{3}=R_{4}=R_{5}=R_{6}=H, R_{2}=$ isoprenyl

$101 \mathrm{R}_{1}=\mathrm{R}_{3}=\mathrm{R}_{5}=\mathrm{R}_{6}=\mathrm{H}, \mathrm{R}_{2}=\mathrm{R}_{4}=$ isopreny

$102 R_{1}=R_{6}=$ isoprenyl, $R_{2}=R_{4}=H, R_{3}=O H, R_{5}=C_{3}$

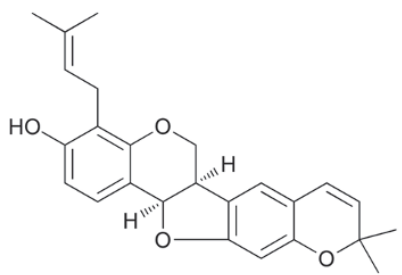

99

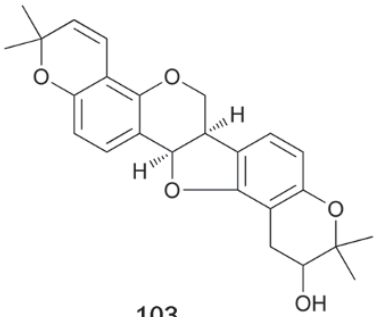

103

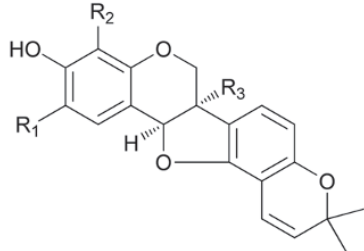

$96 \mathrm{R}_{1}=\mathrm{R}_{3}=\mathrm{H}, \mathrm{R}_{2}=$ isoprenyl $98 R_{1}=$ isoprenyl, $R_{2}=R_{3}=H$ $100 \mathrm{R}_{1}=$ isoprenyl, $\mathrm{R}_{2}=\mathrm{H}, \mathrm{R}_{3}=\mathrm{OH}$

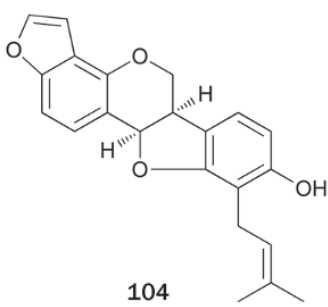

Figure 4. Structures of flavonoids 80-104.

myces (unknown species), exhibited inhibitory activity with an IC value of $20.4 \pm 1.9 \mu \mathrm{mol} / \mathrm{L}^{[79]}$.

PTP1B inhibitors 141 and $142^{[80]}, \mathbf{1 4 3 - 1 4 5 ^ { [ 8 1 ] } \text { , and 146-148 }}{ }^{[82]}$, respectively, were isolated from the $\mathrm{MeOH}$ extracts of the Antarctic lichens Lecidella carpathica, Umbilicaria antarctica, and Stereocaulon alpinum by Seo et al. Although phenolic acids 143-145 share a similar structural pattern with the monomeric hydroxylbenzoic acid, compound $\mathbf{1 4 3}$ showed the strongest inhibitory effect $\left(\mathrm{IC}_{50}=3.6 \pm 0.04 \mu \mathrm{mol} / \mathrm{L}\right)^{[81]}$, suggesting that the molecular size could be an important factor for the activity among these compounds. The fact that the activity of methyl ester derivative of $\mathbf{1 4 3}$ was four-fold weaker than that of 143, suggests that the acid functionality in 143 was crucial to exhibiting the inhibitory activity. Phenol acids 146-148 exhibited potent inhibitory activity with $\mathrm{IC}_{50}$ values of $0.87,6.86$, and $2.48 \mu \mathrm{mol} / \mathrm{L}$, respectively ${ }^{[82]}$. The preliminary SAR from 146-148 indicated that the presence of acidic protons was, at least in part, required in the inhibition mechanism, presumably to provide hydrogen-bonding sites that were relevant to the interaction with PTP1B. Kinetic analysis suggested that 142 inhibited PTP1B activity in a competitive manner ${ }^{[80]}$, while 143, 146, and 147 inhibited PTP1B activity in non-competitive manner ${ }^{[81,82]}$.

KS-506a 149 and KS-506m 150, both containing sulfur atoms, were PTP1B inhibitors both isolated from the culture of the fungus Mortierella vinacea ${ }^{[83]}$. KS-506a 149 showed potent inhibitory activity with an $\mathrm{IC}_{50}$ value of $4.9 \mu \mathrm{mol} / \mathrm{L}$, while KS-506m 150 showed moderate inhibitory activity $\left(\mathrm{IC}_{50}=69.9\right.$ $\mu \mathrm{mol} / \mathrm{L})$. Kinetic analysis suggested that 149 was a competitive inhibitor with a $K_{i}$ value of $2.7 \mu \mathrm{mol} / \mathrm{L}$. Additionally, both compounds showed no inhibitory effects toward other PPs, such as VHR and PP1, at levels up to $200 \mu \mathrm{mol} / \mathrm{L}$.

Caloporoside 151, originally found as a phospholipase C inhibitor isolated from the fungus Caloporus dichrous, was totally synthesized in $1998^{[84]}$. Later, compound 151 was found to inhibit PTP1B with an $\mathrm{IC}_{50}$ value of $1.6 \pm 0.8 \mu \mathrm{mol} / \mathrm{L}$, approximately three-fold in inhibitory activity against $\mathrm{Cdc} 25 \mathrm{~A}^{[85]}$. During a bioassay-guided study on the EtOAc extract of a culture broth of the marine-derived fungus Cosmospora (unknown species), aquastatin A 152 was isolated as a PTP1B inhibitor with an $\mathrm{IC}_{50}$ value of $0.19 \mu \mathrm{mol} / \mathrm{L}^{[86]}$. Kinetic analyses suggested that 152 competitively inhibited PTP1B and showed modest but selective inhibitory activity against PTP1B over other PTPs, such as TCPTP, SHP-2, LAR, and CD45.

1,2,3,4,6-penta-O-galloyl-D-glucopyranose 153, a PTP1B inhibitor $\left(\mathrm{IC}_{50}=4.8 \mu \mathrm{mol} / \mathrm{L}\right)$ isolated from the roots of plant Paeonia lactiflora, was shown to act as an insulin sensitizer in human hepatoma cells (HCC-1.2) at $10 \mu \mathrm{mol} / \mathrm{L}^{[87,88]}$. Additionally, 153 inhibited TCPTP with an $\mathrm{IC}_{50}$ value of $0.07 \mu \mathrm{mol} / \mathrm{L}$, but did not inhibit LAR and SHP-2 at concentrations below 50 


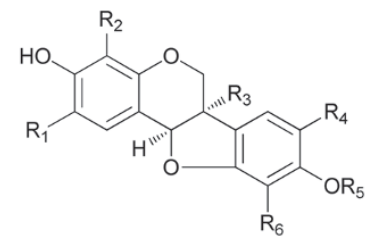

$105 R_{1}=R_{3}=R_{5}=H, R_{2}=R_{6}=$ isoprenyl, $R_{4}=C H O$

$108 R_{1}=R_{2}=R_{4}=H, R_{3}=O H, R_{5}=C_{3}, R_{6}=$ isoprenyl

$112 R_{1}=$ isoprenyl, $R_{2}=R_{3}=R_{4}=R_{5}=R_{6}=H$

$114 R_{1}=R_{3}=R_{4}=R_{5}=H, R_{2}=R_{6}=$ isoprenyl

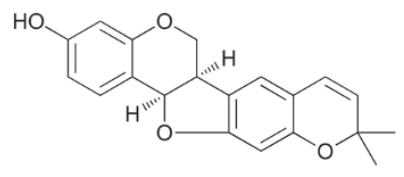

106

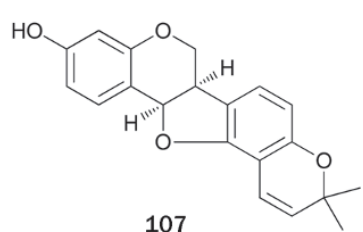

107

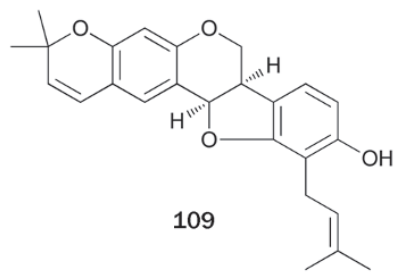

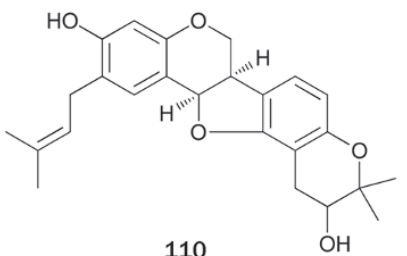

110

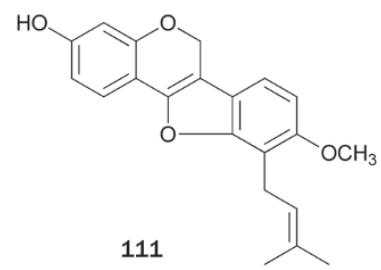

111

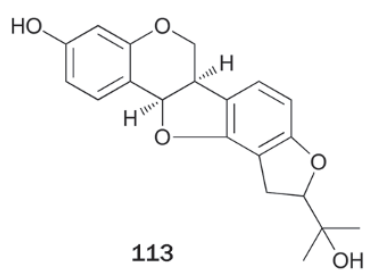

113<smiles>CS(=O)(=O)c1cc(O)c2c(c1-c1cc(-c3cc(=O)c4c(O)cc(O)cc4o3)ccc1O)CC(c1ccc(O)cc1)=CC2=O</smiles><smiles>CC(C)=CC[C@]12Oc3cc(O)c([C@H]4C=C(C)C[C@H](c5ccc(O)cc5O)[C@H]4C(=O)c4ccc(O)cc4O)c(O)c3C(=O)[C@]1(O)Oc1cc(O)ccc12</smiles>

116

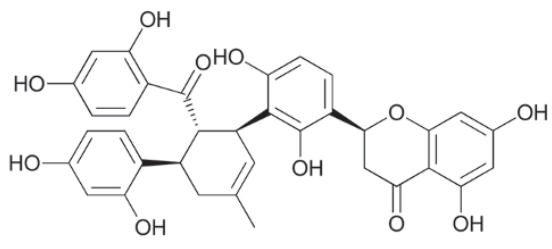

117<smiles>CC(C)=CCCC1=C[C@H](c2c(O)cc3c(c2O)C(=O)CC(c2ccc(O)cc2O)O3)[C@H](c2ccc(O)cc2O)C(c2ccc(O)cc2O)C1</smiles>

118

Figure 5. Structures of flavonoids 105-118.

$\mu \mathrm{mol} / \mathrm{L}$ (Figure 7).

\section{Phenolics containing furan or pyran rings}

Two 2-arylbenzofuran PTP1B inhibitors, glycybenzofuran 154 and licocoumarone 155, were isolated from the roots of the plant Glycyrrhiza uralensis ${ }^{[33]}$. Compound 154 showed stronger inhibitory activity in vitro with an $\mathrm{IC}_{50}$ value of $25.5 \mu \mathrm{mol} / \mathrm{L}$ by a competitive manner.

The bioassay-guided fractionation of 'Sang-Bai-Pi' mentioned above also resulted in isolation of mulberrofuran $\mathrm{C}$ 156, which inhibited PTP1B with an $\mathrm{IC}_{50}$ of $4.9 \pm 0.2 \mu \mathrm{mol} / \mathrm{L}$ in a mixed-type manner ${ }^{[66]}$. The bioassay for the inhibitory effects on other PPs showed that $\mathbf{1 5 6}$ had no inhibitory effects toward VHR and PP1 at levels up to $50 \mu \mathrm{mol} / \mathrm{L}$. Albafuran A 157, mulberrofurans W 158 and D 159 were isolated from the chloroform-soluble fraction of the plant Morus bombycis ${ }^{[34]}$. An analysis of the inhibition kinetics suggested 157-159 inhibited PTP1B in a mixed-type manner $\left(\mathrm{IC}_{50}\right.$ values ranging from 2.7 to $9.2 \mu \mathrm{mol} / \mathrm{L})$. The respective lipophilic and hydroxyl groups of 157-159 are considered to play an important role in inhibition of PTP1B.

2-Arylbenzofurans 160-165 were isolated from the plant Erythrina addisoniae by $\mathrm{Na}$ et $a l^{[89]}$. Compounds 160-162 inhib- ited PTP1B $\left(\mathrm{IC}_{50}\right.$ values ranging from $13.6 \pm 1.1$ to $17.5 \pm 1.2$ $\mu \mathrm{mol} / \mathrm{L}$ in vitro assay) much more strongly than 163-165 $\left(\mathrm{IC}_{50}\right.$ values ranging from $62.7 \pm 2.0$ to $74.1 \pm 1.9 \mu \mathrm{mol} / \mathrm{L}$ ), indicating that cyclization between an isoprenyl group and one of the phenolic hydroxyl group in ring B or loss of the isoprenyl group might be responsible for the loss of in vitro activity.

Dibenzofuran derivatives 166 and its sulfate adduct 167 were isolated from the green alga Cladophora socialis, which was supplied by the Queensland Museum ${ }^{[0]}$. Both dibenzofurans showed potent inhibitory activity against PTP1B, with $\mathrm{IC}_{50}$ values of 3.7 and $1.7 \mu \mathrm{mol} / \mathrm{L}$. It was speculated that the dibenzofuran and phenyl ring systems at each end of 166 acted as two binding sites with PTP1B, and the phenyl ring in the middle of $\mathbf{1 6 6}$ acted as the linker. The carboxyl group at C-3 and the phenolic hydroxyl group at C-4" may contribute to the binding, while the presence of more highly acidic sulfate functionality at C-4" in $\mathbf{1 6 7}$ may enhance its activity (Figure 8).

Usimines A-C 168-170 and usnic acid 171, were isolated from a MeOH extract of the Antarctic lichen Stereocaulon alpi$n u m^{[91]}$. The absolute configurations of the chiral centers in 168-170 were determined by comparison of optical rotations and Marfey's derivatization of the mixture from acid hydrolysis. Compounds 168-171 showed inhibitory activity with 
<smiles>OCc1cc(O)c(O)c(Br)c1Cc1cc(O)c(O)c(Br)c1</smiles>

119<smiles>[R7]Oc1cc(O)c(O)c(Br)c1Cc1cc(O)c(O)c(Br)c1[R2]</smiles><smiles>Cc1cc(C)c(Oc2cc(Br)cc(Br)c2Br)c(Br)c1</smiles>

129<smiles>Oc1cc(Cc2cc(O)c(O)c(Br)c2Br)c(Br)c(Br)c1O</smiles>

120<smiles>Oc1cc(Cc2c(Cc3cc(O)c(Br)c(Br)c3Br)cc(O)c(O)c2Br)c(Br)c(Br)c1O</smiles><smiles>COCc1cc(O)c(O)c(Br)c1Br</smiles>

124<smiles>CC(C=O)Cc1cc(O)c(O)c(Br)c1Br</smiles>

125<smiles>Oc1cc(COCc2cc(O)c(O)c(Br)c2Br)c(Br)c(Br)c1O</smiles>

122<smiles>Oc1cc(C2OCc3cc(O)c(O)c(Br)c32)c(Br)c(Br)c1O</smiles>

126<smiles>Oc1c(O)c(Br)c(Cc2c(Br)c(Br)c(O)c(Br)c2Br)c(Br)c1Br</smiles>

133<smiles>COc1cc(C(=O)c2c(Br)c(Br)c(OC)c(OC)c2Br)c(Br)c(Br)c1OC</smiles>

130<smiles>O=Cc1c(Br)c(O)c(O)c(Br)c1Br</smiles>

131<smiles>COCc1c(Br)c(O)c(O)c(Br)c1Br</smiles>

132

Figure 6. Structures of bromophenols 119-135.

$\mathrm{IC}_{50}$ values ranging from $15.0 \pm 0.1$ to $27.7 \pm 2.1 \mu \mathrm{mol} / \mathrm{L}$. Synthesis of $\mathbf{1 7 1}$ from commercially available starting material was achieved in two steps, the methylation of phloracetophenone followed by oxidation with horseradish peroxidase ${ }^{[2]}$.

A tricyclic polyketide ortho-quinone, nocardione A 172, was produced by the fungus Nocardiam (unknown species) ${ }^{[93]}$. Compound 172 showed inhibition of intracellular PTP1B with a similar potency to $\mathrm{Cdc} 25 \mathrm{~b}\left(\mathrm{IC}_{50}=17 \mu \mathrm{mol} / \mathrm{L}\right)$ and showed weaker inhibition of FAP-1 $\left(\mathrm{IC}_{50}=89 \mu \mathrm{mol} / \mathrm{L}\right)$. Additionally, it showed moderated in vitro antifungal and cytotoxic activities. In 2001, two routes for total synthesis of $\mathbf{1 7 2}$ were achieved by starting from a propylene oxide and a 5-benzyloxy-1-tetralone, chloropropene and 5-methoxyl-1-naphthol, respectively ${ }^{[94,95]}$. Clive et al reported another route based on a method for achieving formal cyclization of a radical onto a benzene ring to synthesized (+)-172 $2^{[96,97]}$

Ohioensins A 173, C 174, F 175, and G 176 were isolated from the $\mathrm{MeOH}$ extract of the Antarctic moss Polytrichastrum alpinum $^{[98]}$. All these compounds showed inhibitory activity with $\mathrm{IC}_{50}$ values ranging from $3.5 \pm 0.2$ to $7.6 \pm 0.7 \mu \mathrm{mol} / \mathrm{L}$.
Kinetic analysis of PTP1B inhibition by $\mathbf{1 7 5}$ suggested that these benzopyrans inhibited PTP1B activity in a non-competitive manner.

Chemical investigation of the species of fungus Phelliuns resulted in the isolation of several a-pyrone PTP1B inhibitors, such as pyrano[4,3-c]isochromen-4-one derivatives, phelligridins H 177 and I 178 from $P$ igniarius $^{[99]}$, and hispidin derivatives, phelligridimer A 179, davallialactone 180, hypholomine B 181, interfungins A 182 and inoscavin A 183 from P linteus ${ }^{[7]}$. Phelligridins 180 and $\mathbf{1 8 1}$ inhibited PTP1B with $\mathrm{IC}_{50}$ values of 3.1 and $3.0 \mu \mathrm{mol} / \mathrm{L}$, respectively, and also exhibited antioxidant activity against rat liver microsomal lipid peroxidation. Compounds 180 and $\mathbf{1 8 1}$ with a hispidin moiety exhibited higher inhibitory activity than $\mathbf{1 7 9}, \mathbf{1 8 2}$, and $\mathbf{1 8 3}$ (Figure 9).

\section{Coumarins and lignans}

Coumarin is a fragrant chemical compound of benzopyrone found in many plants. It has a distinctive odor which has led to its use as a food additive and ingredient in perfume. Natural coumarin displays extensively interesting bioactivities, 
<smiles>O=C(O)C=Cc1ccc(O)c(O)c1</smiles>

136<smiles>O=C1OC2(O)C(C(O)C(=O)C[C@@H]2c2ccc(O)c(O)c2)C(O)C1O</smiles>

137<smiles>O=C(O)c1ccc(O)c(O)c1</smiles>

138<smiles>O=c1oc2c(O)c(O)cc3c(=O)oc4c(O)c(O)cc1c4c23</smiles>

139<smiles>Nc1c(O)ccc(O)c1C(=O)O</smiles>

140<smiles>COc1cc(C)c(C)c(OC(=O)c2c(C)c(C)c(OC)c(C)c2OC)c1C</smiles>

141<smiles>CC(=O)c1c(C)cc(O)c(C)c1O</smiles>

142<smiles>Cc1cc(OC(=O)c2c(C)cc(OC(=O)c3c(C)cc(O)cc3O)cc2O)cc(O)c1C(=O)O</smiles>

143<smiles>CCCCCc1c2c(cc(O)c1C(=O)O)OC(=O)c1c(cc(OC)cc1C(=O)CCCC)O2</smiles><smiles>CCCCCc1cc(O)cc(O)c1Oc1cc(OC)cc2c1C(=O)OC2(CC)OC</smiles>

147<smiles>CCCCCc1c(O)cc(O)c(C(=O)O)c1Oc1cc(OC)cc2c1C(=O)OC2(C)CCCC</smiles><smiles>Cc1c(C)c(C)c(C(=O)Oc2c(C)c(O)c(C)c(C)c2C(=O)SSC(=O)c2c(C)c(C)c(O)c(C)c2OC(=O)c2c(C)c(C)c(O)c(C)c2O)c(O)c1C</smiles><smiles>Cc1c(C)c(C(=O)SCC(=O)CCSC(=O)c2c(C)c(O)c(C)c(C)c2O)c(C)c(C)c1O</smiles>

148

149<smiles>CC(=O)O[C@H](C)CCCCCCCCCCCCCCCc1cccc(O)c1C(=O)O</smiles><smiles>CCCCCCCCCCCCCCc1cc(OC2OC(CO)C(O)C(O)C(O)C2O)cc(O)c1C(=O)Oc1cc(C)c(C(=O)O)c(O)c1</smiles>

$\mathrm{HO}$<smiles>O=C(COC(OC(=O)c1cc(O)c(O)c(O)c1)C(CCOC(=O)c1cc(O)c(O)c(O)c1)OC(=O)c1cc(O)c(O)c(O)c1)OCCCCOC(=O)c1cc(O)c(O)c(O)c1</smiles>

153

Figure 7. Structures of phenolic acids 136-153.

intriguing chemists and medicinal chemists for decades to explore their applicability as drugs ${ }^{[100-102]}$. Lignans are phenylpropanoid demers, where the phenylpropane units are linked by the central carbon (C8) of their side chains. Lignans also have a number of medically important biological activities, eg, antitumor, antimitotic and antiviral properties ${ }^{[103]}$. However, there are only a few reports about natural coumarins or lignans with PTP1B inhibitory activity.

The seed of the plant Psoralea corylifolia is a commonly used traditional Chinese medicine against gynecological bleeding, vitiligo and psoriasis. Bioassay-guided fractionation of the EtOAc-soluble extract of $P$ corylifolia produced psoralidin 184, 


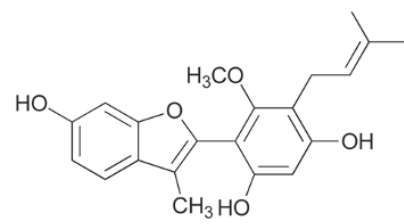

154

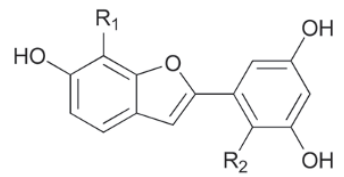

$157 R_{1}=H, R_{2}=$ geranyl $158 \mathrm{R}_{1}=\mathrm{H}, \mathrm{R}_{2}=$ farnesyl $159 R_{1}=$ geranyl, $R_{2}=$ prenyl

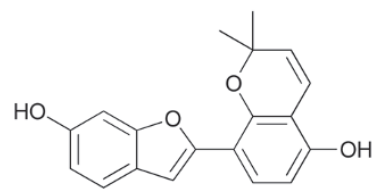

163
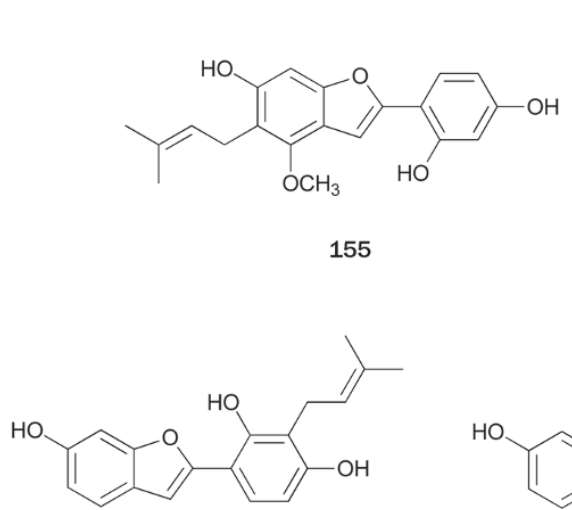

160<smiles>O=C(c1ccc(O)cc1O)[C@@H]1[C@@H](c2ccc(O)cc2O)CC(O)=C[C@H]1c1c(O)cc(-c2cc3ccc(O)cc3o2)cc1O</smiles>

156

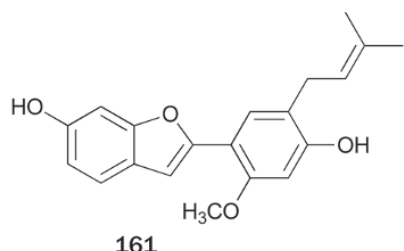<smiles>COc1cc(O)ccc1-c1cc2cc(CC=C(C)C)c(O)cc2o1</smiles>
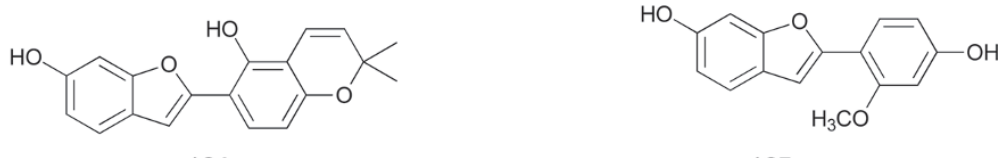

165

Figure 8. Structures of phenolics containing furan or pyran ring 154-165.

which is a non-competitive PTP1B inhibitor with an $\mathrm{IC}_{50}$ value of $9.4 \pm 0.5 \mu \mathrm{mol} / \mathrm{L}$ that showed no inhibitory effects toward VHR and PP1 at levels up to $100 \mu \mathrm{mol} / \mathrm{L}^{[104]}$. Chemical studies on the roots of plant Fraxinus rhynchophylla (Qinpi), a traditional Chinese herbal drug used as anti-inflammatory agent, led to the isolation of a coumarin-secoiridoid hybrid glycoside, fraxisecoside 185. Compound 185 exhibited moderate inhibitory activity $\left(\mathrm{IC}_{50}=21 \mu \mathrm{mol} / \mathrm{L}\right)$ and inhibited the proliferation of the lymphocyte T and B cells ${ }^{[105]}$. Glycycoumarin 186, isolated from the roots of the plant $G$ uralensis, showed weak inhibitory activity with an $\mathrm{IC}_{50}$ value of $183.9 \pm 4.5 \mu \mathrm{mol} / \mathrm{L}^{[33]}$. A based-catalyzed condensation of phenyl acetate with acid chloride, followed by intramolecular cyclization and microwave-assisted cross-metathesis reaction, led to the first total synthesis of $\mathbf{1 8 4 ^ { [ 1 0 6 ] }}$.

Bioassay-guided fractionation of the $\mathrm{MeOH}$ extract of plant Myristica fragrans Houtt (Myristicaceae) afforded mesodihydroguaiaretic acid 187 and otobaphenol 188 ${ }^{[107]}$. Both compounds inhibited PTP1B with $\mathrm{IC}_{50}$ values of $19.6 \pm 0.3$ and $48.9 \pm 0.5 \mu \mathrm{mol} / \mathrm{L}$, respectively, in a non-competitive manner. Compound $\mathbf{1 8 7}$ was reported to increase the tyrosine phosphorylation of $32 \mathrm{D}$ cells overexpressing the IR in a dose-dependent manner, possibly through the inhibition of PTP1B activity. 1,4-Benzodioxane lignan 189, isolated from the $\mathrm{MeOH}$ extract of the plant Artemisia minor collected from Tibet, inhibited PTP1B with an $\mathrm{IC}_{50}$ of $1.62 \mu \mathrm{g} / \mathrm{mL}^{[108]}$ (Figure 10).

\section{Miscellaneous}

Bakuchiol 190, isolated from the extract of the seeds of the plant Psoralea corylifolia, was found to inhibit PTP1B in a dose- dependent manner with an $\mathrm{IC}_{50}$ value of $20.8 \pm 1.9 \mu \mathrm{mol} / \mathrm{L}$ and with good selectivity against other PPs, such as VHR and PP1 $\left(\mathrm{IC}_{50}>100 \mu \mathrm{mol} / \mathrm{L}\right)^{[104]}$. The first enantiocontrolled synthesis of 190 was completed by starting from (S)-O-benzylglycidol ${ }^{[109]}$. Later, several simple and convenient methods were reported for the total synthesis of $\mathbf{1 9 0} 0^{[110-114]}$.

A study on the constituents of the mangrove plant Lumnitzera racemosa produced two alkylphenols 191 and $192^{[115]}$. Both alkylphenols showed inhibitory activity with $\mathrm{IC}_{50}$ values of $13.38 \pm 1.98$ and $10.40 \pm 0.88 \mu \mathrm{mol} / \mathrm{L}$, respectively. Alkylphenol 192 had been synthesized in 1989 to test for cytotoxicity against the $\mathrm{KB}$ cell lines $\left(\mathrm{ED}_{50}=2.4 \mu \mathrm{mol} / \mathrm{mL}\right)^{[116]}$.

Curcumin 193, the principal constituent of the rhizomes of the plant Curucma longa $a^{[117]}$, was found to inhibit PTP1B and subsequently improve insulin and leptin sensitivity in the liver of rats, which protects against fructose-induced hypertriglyceridemia and hepatic steatosis ${ }^{[118]}$. Compound 193 was prepared by condensing dimethyl malonate with vanillin in the presence of $\mathrm{B}_{2} \mathrm{O}_{3}$ and $(\mathrm{BuO})_{3} \mathrm{~B}$ to prevent Knoevenagel condensation $^{[119,120]}$.

4-Di-O- $\beta$ - $D$-glucopyranoside 194, isolated from the leaves of the plant Cyclocarya paliurus, showed inhibitory activity against PTP1B with an $\mathrm{IC}_{50}$ value of $10.50 \pm 2.67 \mu \mathrm{mol} / \mathrm{L}^{[35]}$.

Physcion 195, isolated from the ethanol extract of the plant Ardisia japonica, showed weak inhibitory activity ${ }^{[121]}$. The total synthesis of 195 was completed in two steps by the regioselective two-fold Diels-Alder reaction ${ }^{[122]}$.

From the EtOH extract of the roots of the plant Saussurea lappa, Li et al also obtained three PTP1B inhibitors, including chrysophanol 196 and its glucopyranoside derivatives 197 and $\mathbf{1 9 8} 8^{[123]}$. The first total synthesis of $\mathbf{1 9 6}$ was achieved by the 
<smiles>O=C(O)c1cc2oc3c(Oc4ccc(-c5ccc(O)c(O)c5)cc4O)cc(O)cc3c2cc1O</smiles>

$166 \mathrm{R}=\mathrm{H}$ $167 \mathrm{R}=\mathrm{SO}_{3} \mathrm{H}$

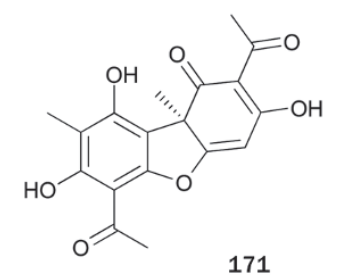

171<smiles>O=C1C[C@H]2c3ccccc3O[C@H]3c4cc(O)ccc4-c4c(O)cc(O)c(c42)[C@H]13</smiles><smiles></smiles><smiles>CC(C)(C)[N+]1=CC(=Cc2ccc(O)c(O)c2)OC(c2ccc(O)c(O)c2)C1C1C=C(O)CC(=O)O1</smiles><smiles>CC(=O)c1c(O)c(C)c(O)c2c1OC1=CC(O)=C(/C(C)=N/C(CCC(=O)O)C(=O)O)C(=O)C12C</smiles><smiles>CC1CC2=C(O1)c1cccc(O)c1C2=O</smiles><smiles>O=C1C[C@H]2c3ccccc3O[C@H]3c4c(O)cc(O)cc4-c4c(O)cc(O)cc4[C@H]1[C@H]23</smiles><smiles>O=C1CC2c3ccccc3O[C@H]3c4cccc(O)c4-c4c(O)cc(O)c(c42)C13</smiles>

174<smiles>O=C1c2c(O)cc(O)c3c2[C@@H](c2cccc(O)c2-3)[C@H]2Oc3ccccc3[C@@H]1[C@H]2O</smiles>

176<smiles></smiles><smiles>CC1=CC(=O)C(c2c(O)cc(/C=C/c3ccc(O)c(O)c3)oc2=O)C(c2ccc(O)c(O)c2)O1</smiles><smiles>CC(=O)/C=C(O)\C(=C/c1ccc(O)c(O)c1)c1c(O)cc(/C=C/c2ccc(O)c(O)c2)oc1=O</smiles><smiles>CC1=CC(=O)C2(Oc3cc(/C=C/c4ccc(O)c(O)c4)oc(=O)c3C2c2ccc(O)c(O)c2)C1=O</smiles>

Figure 9. Structures of phenolics containing furan or pyran ring 166-183.

cycloaddition reaction of 6-methoxy-3-methyl-2-pyrone with naphthoquinone as the key step ${ }^{[124]}$. In 1990, another synthetic route for 196 using dihydro-oxazoles and Grignard reagents from $\mathrm{Mg}$ (Anthracene) $(\mathrm{THF})_{3}$ was reported ${ }^{[125]}$.

A phenanthraquinone-type metabolite 199, with inhibitory activity with an $\mathrm{IC}_{50}$ value of $38.0 \pm 1.5 \mu \mathrm{mol} / \mathrm{L}$, was isolated from the EtOAc-soluble extract of the plant Dendrobium moniliforme ${ }^{[126]}$. Compound 199 showed no inhibition against PP1 at levels up to $200 \mu \mathrm{mol} / \mathrm{L}$, but lacked selectivity against PTP1B over VHR $\left(\mathrm{IC}_{50}=3.0 \pm 1.5 \mu \mathrm{mol} / \mathrm{L}\right)$.

Grecocycline B 200, an angucycline with a thiol substitution at C-6a, was isolated from fungus Streptomyces (unknown spe- 
<smiles>CC(C)=CCc1cc2c(cc1O)oc(=O)c1c3ccc(O)cc3oc21</smiles>

184<smiles>COc1cc(CC(C)C(C)Cc2ccc(O)c(OC)c2)ccc1O</smiles>

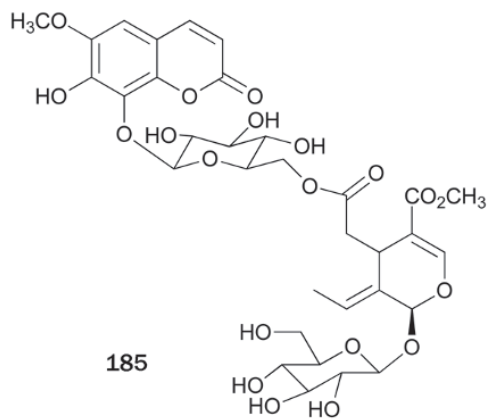<smiles>COc1cc2c(cc1O)[C@@H](c1ccc3c(c1)OCO3)[C@H](C)C(C)C2</smiles><smiles>COc1c(CC=C(C)C)c(O)cc2oc(=O)c(-c3ccc(O)cc3O)cc12</smiles>

186<smiles>COc1cc(C2Oc3cc(/C=C/C(=O)O)ccc3OC2CO)ccc1O</smiles>

189

Figure 10. Structures of coumarins and lignans 184-189.

(ies) ${ }^{[127]}$. Compound 200 was reported to exhibit strong inhibitory activity with an $\mathrm{IC}_{50}$ value of $0.52 \pm 0.17 \mu \mathrm{mol} / \mathrm{L}$. The free $\mathrm{SH}$ group in the C-6a position is proposed to be responsible for the irreversible inhibition of PTP1B (Figure 11).

\section{Terpenes}

Terpenes are a large and varied class of organic compounds produced by a wide variety of plants, animals, and marine organisms. Terpenes, which are derived biosynthetically from units of isoprene $\left(\mathrm{C}_{5} \mathrm{H}_{8}\right)$, are classified sequentially by size as hemiterpenes, monoterpenes, sesquiterpenes, diterpenes, sesterterpenes, triterpenes, tetraterpenes, and polyterpenes. Naturally occurring terpenes usually display remarkable pharmacological activities, including antitumor, antimicrobial, antifungal, antiviral, anti-hyperglycemic, anti-inflammatory, and antiparasitic activities as well as a skin permeability effect ${ }^{[28,129]}$. There are also many terpenes, primarily sesquiterpenes, diterpenes, sesterterpenes, triterpenes, that are found<smiles>C=CC(C)(C=Cc1ccc(O)cc1)CCC=C(C)C</smiles>

190<smiles>COc1cc(/C=C/C(=O)/C=C(O)/C=C/c2ccc(O)c(OC)c2)ccc1O</smiles>

193

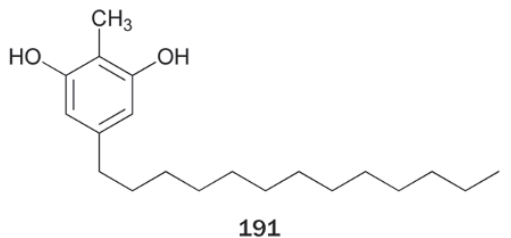

191

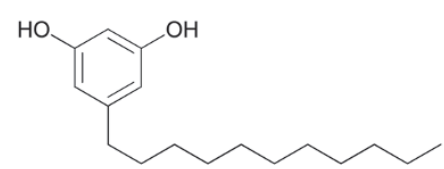

192

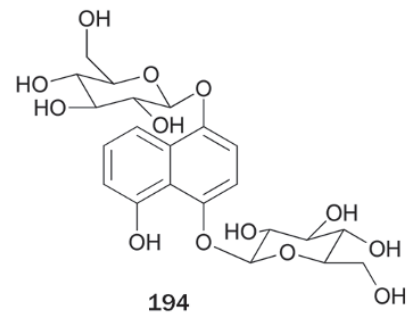<smiles>COc1cc(O)c2c(c1)C(=O)c1cc(C)cc(O)c1C2=O</smiles>

195<smiles>Cc1cc(O)c2c(c1)C(=O)c1cccc(O)c1C2=O</smiles>

196

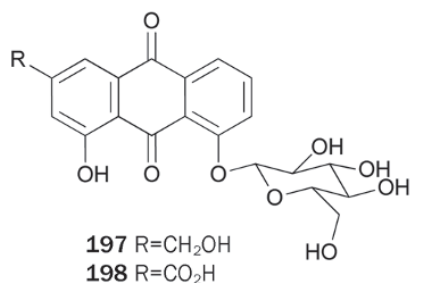

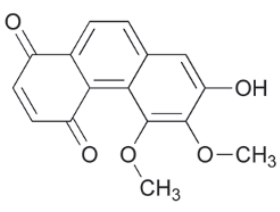

199

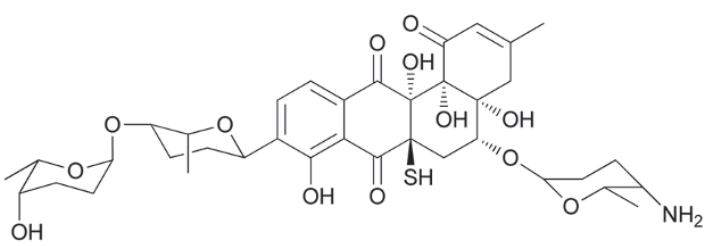

200

Figure 11. Structures of coumarins and lignans 190-200. 
to act as PTP1B inhibiters.

\section{Sesquiterpenes}

The plant Ligularia fischeri is common in southwestern China and has been used as a traditional Chinese medicine since ancient time. From the roots of $L$ fischeri, an eremophilane sesquiterpene 201 was isolated ${ }^{[130]}$. Its structure was elucidated by spectroscopic methods including 1D and 2D NMR spectra and was further confirmed by a single-crystal X-ray diffraction analysis. Sesquiterpene 201 exhibited in vivo inhibitory activity with an $\mathrm{IC}_{50}$ value of $1.34 \mu \mathrm{mol} / \mathrm{L}$.

O-Methyl nakafuran-8 lactone 202 was isolated from a Hainan sponge Dysidea (unknown species) and its structure proposed by spectral data was confirmed by X-ray diffraction analysis ${ }^{[131]}$. Lactone 202 showed strong inhibitory activity with an $\mathrm{IC}_{50}$ value of $1.58 \mathrm{\mu mol} / \mathrm{L}$. Further studies on several species of Dysidea from Hainan produced other sesquiterpene PTP1B inhibitors, such as 203-206 from D septosa ${ }^{[132]}$, and 207 and 208 from $D$ villosa ${ }^{[133]}$. Sesquiterpene 203 had the strongest inhibitory effect among 203-206 ${ }^{[132]}$. Compound 207, a member of the family of sesquiterpene quinine derivatives with a further rearranged drimane skeketon characterized by the abnormal position of the quinine moiety, showed moderate inhibitory activity and moderate cytotoxicity against HeLa cell lines. Moreover, 208 showed much stronger inhibitory activity with an $\mathrm{IC}_{50}$ value of $6.70 \mathrm{\mu mol} / \mathrm{L}$. More-in-depth pharmacology studies revealed that $\mathbf{2 0 8}$ is a novel slow-binding PTP1B inhibitor with moderate inhibitory selectivity over other PTPS. Further cell based evaluation indicated that $\mathbf{2 0 8}$ could strongly activate the insulin signaling pathway and promote membrane translocation of the glucose transporter 4 (GLUT4) in CHOK1 and 3T3-L1 cells. Additionally, 208 could significantly increase glucose uptake in 3T3-L1 cells by 2.3 fold $^{[133]}$. The total synthesis of $\mathbf{2 0 4}$ was accomplished starting from 1-methoxy-4,5,8-endo-trimethylbicyclo[2.2.2]oct-5-en-2-one by a rearrangement strategy ${ }^{[134,135]}$. The absolute configuration of 207 was confirmed by total synthesis with the key reaction being a Chiron-mediated asymmetric Aza-Claisen rearrangement ${ }^{[136]}$.

Lactucin 209, isolated from the root of the plant Cichorium glandulosum, was reported to inhibit PTP1B with an $\mathrm{IC}_{50}$ value of $\approx 1 \mu \mathrm{mol} / \mathrm{L}^{[137]}$. Activity-guided fractionation of a $\mathrm{MeOH}$ extract of the roots of the plant Saussurea lappa led to the isolation of guaiane sesquiterpenoids, mokko lactone 210 and dehydrocostuslactone $\mathbf{2 1 1}$ with inhibitory activity $\left(\mathrm{IC}_{50}=1.41 \pm 0.02 \text { and } 6.51 \pm 0.64 \mu \mathrm{g} / \mathrm{mL} \text {, respectively }\right)^{[138]}$. The lactones 210 and 211 were first synthesized in $1984^{[139]}$. Later, they were synthesized with their related guaianolides, starting from 1-a-santonin, in an effort to examine their SAR as inhibitors as the killing function of cytotoxic $\mathrm{T}$ lymphocytes (CTL) and the induction of intercellular adhesion molecule-1 $\left(\right.$ ICAM-1) ${ }^{[140]}$.

Psidials B 212 and C 213 are sesquiterpenoid-based meroterpenoids representing the new skeleton of the 3,5-diformylbenzyl phloroglucinol-coupled sesquiterpenoid. Compounds 212 and 213 were isolated from the leaves of the plant Psidium guajava, which is used in folk medicine as anti-inflammatory and hemostatic agents and for treating pulmonary disease, cough, vomiting, and diarrhea ${ }^{[141]}$. Their complete structures were elucidated by spectral and chemical methods. Both psidials showed inhibitory activity at the concentration of $10 \mu \mathrm{mol} / \mathrm{L}$ (Figure 12).

\section{Diterpenes}

Kaurane-type diterpenes 214-216 were isolated from a $\mathrm{MeOH}$ extract of the aerial part of the plant Siegesbeckia glabrescens ${ }^{[142]}$. Diterpene 214, possesssing an isobutyryloxyl moiety at C-17 of the kaurane skeleton, exhibited the strongest inhibitory activity $\left(\mathrm{IC}_{50}=8.7 \pm 0.9 \mu \mathrm{mol} / \mathrm{L}\right)$ among these isolates. Compound 215, with an acetoxy and an isobutyryloxy group at C-17 and $\mathrm{C}-18$, respectively, inhibited PTP1B with an $\mathrm{IC}_{50}$ value of $30.6 \pm 2.1 \mu \mathrm{mol} / \mathrm{L}$, which was less effective than 214. However, compound $216\left(\mathrm{IC}_{50}>200 \mu \mathrm{mol} / \mathrm{L}\right)$, substituted with a hydroxyl group at C-17, exhibited significantly lower activity than 214, suggesting that an ester moiety at C-17 of the kaurane diterpene is essential for activity. Additionally, 214 and 215 had no inhibitory effects on VHR and PP1 at levels up to $200 \mu \mathrm{mol} / \mathrm{L}$ and kinetic analyses suggested that both compounds are noncompetitive inhibitors with $K_{\mathrm{i}}$ values of 9.1 and $31.8 \mu \mathrm{mol} / \mathrm{L}$, respectively.

The roots and stem barks of the plant Acanthopanax koreanum have been traditionally used as a tonic and to treat rheumatism, hepatitis, and diabetes in Korea. Diterpenes 217-224 were isolated from a $\mathrm{CH}_{2} \mathrm{Cl}_{2}$-soluble extract of the roots of $A$ koreanum $^{[143]}$. Of the isolates tested, diterpene 223, possessing an isovaleryloxy group at C-17 of kaurane-type, exhibited the most potent inhibitory activity $\left(\mathrm{IC}_{50}=7.1 \pm 0.9 \mu \mathrm{mol} / \mathrm{L}\right)$ by a non-competitive manner. Diterpene $224\left(\mathrm{IC}_{50}>30 \mu \mathrm{mol} / \mathrm{L}\right)$, with a hydroxyl group substituted at C-16 of 223, exhibited significantly lower activity than 223. A similar case was observed between 221 and 222. These results indicate that substitution of a hydroxyl group at C-16 of kaurane-type diterpenes decreases the inhibitory activity. The pimarane-type diterpene 218 inhibited PTP1B in a dose-dependent manner $\left(\mathrm{IC}_{50}=23.5 \pm 1.8 \mu \mathrm{mol} / \mathrm{L}\right)$. However, 217, with conversion of a carboxyl group at C-19 to a primary alcohol, did not exhibit PTP1B inhibitory activity up to $30 \mu \mathrm{mol} / \mathrm{L}$, suggesting that a carboxyl group at C-19 of pimarane-type is essential for the activity. Other pimarane-type diterpenes 219 and 220, with hydroxyl groups at C-7 and C-9, respectively, had no activity at levels up to $30 \mu \mathrm{mol} / \mathrm{L}$. Another three kaurane-type PTP1B inhibitors 225-227 $\left(\mathrm{IC}_{50}=12.6,200,21.3 \mu \mathrm{mol} / \mathrm{L}\right.$, respectively) were isolated from the plant $S$ orientalis ${ }^{[144]}$. Diterpene 218 was synthesized from stevioside via two skeletal rearrangements in nine steps, with a total yield of $9 \%{ }^{[145]}$. An enantioselective synthesis of $\mathbf{2 2 1}$ is described by Ling et al ${ }^{[146]}$.

Bioassay-guided fractionation and purification of the $\mathrm{MeOH}$ extract of the dried root of the plant Salvia miltiorrhiza called 'Dan-Shen' in China, produced three related abietanetype diterpene metabolites, namely isotanshinone IIA 228, dihydroisotanshinone I 229, and isocryptotanshinone $230^{[147]}$. Diterpenes 228-230 non-competitively inhibited PTP1B with $\mathrm{IC}_{50}$ values of $11.4 \pm 0.6,22.4 \pm 0.6$, and $56.1 \pm 6.3 \mu \mathrm{mol} / \mathrm{L}$, 
<smiles>CC(=O)O[C@H]1CC[C@@]2(O)C[C@]3(O)OC(=O)C(C)=C3[C@@H](O)[C@]2(C)[C@@H]1C</smiles>

201<smiles>C=C1CCCC(C)(C)C1CCc1ccoc1</smiles>

206

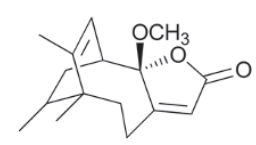

202

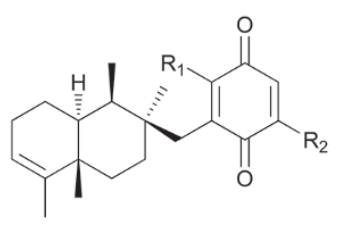

$207 \mathrm{R}_{1}=\mathrm{H}, \mathrm{R}_{2}=\mathrm{OCH}_{3}$ $208 \mathrm{R}_{1}=\mathrm{OH}, \mathrm{R}_{2}=\mathrm{NHCH}_{2} \mathrm{CH}_{2} \mathrm{SO}_{3} \mathrm{H}$

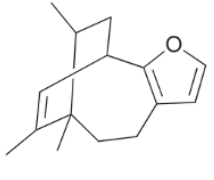

203

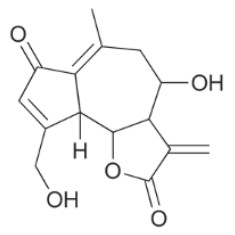

209

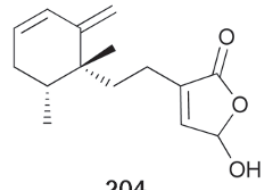

204

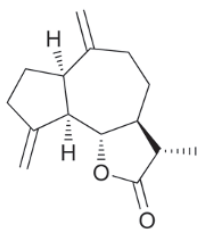

210

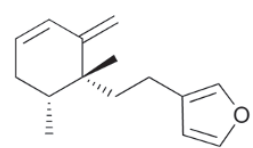

205

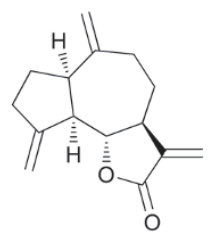

211<smiles>C[C@@H]1[C@@H]2[C@H]3[C@@H](CC[C@]3(C)[C@H](c3ccccc3)c3c(O)c(C=O)c(O)c(C=O)c3O)[C@@H](O)CC[C@@H]2[C@@H]1C</smiles><smiles>C[C@H]1CC[C@H]([C@H](c2ccccc2)c2c(O)c(C=O)c(O)c(C=O)c2O)[C@@]2(C)CCC(C(C)(C)O)C=C12</smiles>

213

Figure 12. Structures of sesquiterpenes 201-213.

respectively. Isotanshinone IIA 228 had been prepared as an intermediate to synthesize tanshinones ${ }^{[148]}$, which were also obtained by partial synthesis from 16-hydroxycarnosol ${ }^{[149]}$.

Lipidyl pseudopteranes A $\mathbf{2 3 1}$ and D 232 were isolated from the soft coral Pseudopterogorgia acerosa collected from the Bahamas ${ }^{[150]}$. Their structures represent the first report of a pseudopterane diterpene with a fatty acid moiety. Compounds $\mathbf{2 3 1}$ and $\mathbf{2 3 2}$ exhibited modest inhibitory activity, but were inactive against other PTPs, including LAR, SHP-1, and MKPX. Their lipidyl moiety appears to aid in their ability to diffuse into mammalian cells and inhibit PTP1B (Figure 13).

\section{Sesterterpenes}

Hyrtiosal 233, a sesterterpenoid possessing a novel, rearranged tricarbocyclic skeleton, was isolated from the Okinawan sponge Hyrtios erectus ${ }^{[151]}$. A possible biosynthesis pathway of 233 was proposed in which the olefinic bond of the tricarbocyclic precursor containing a cheilanthane skeleton is oxidized to give an epoxy intermediate. The subsequent rearrangement produces a ring-contracted hyrtiosane skeleton. Sun et al found that 233 inhibited PTP1B activity in a dose-dependent, non-competitive manner with an $\mathrm{IC}_{50}$ value of $42 \mu \mathrm{mol} / \mathrm{L}^{[152]}$. Further research showed that $\mathbf{2} 3 \mathbf{3}$ displayed potent activity for abolishing the retardation of AKT membrane translocation caused by PTP1B overexpression in CHO cells, dramatically enhanced the membrane translocation of the key glucose transporter Glut4 in PTP1B-overexpressed CHO cells, and effectively facilitated insulin inhibition of Smad2 activation. Moreover, hyrtiosal 233 was found to inhibit HIV-1 integrase from binding to viral DNA by a new inhibitor binding site ${ }^{[153]}$.
The absolute configuration of natural (-)-233 was confirmed by total synthesis, together with its C-16 epimer, starting from sclareol in moderate yield ${ }^{[154,155]}$. Lunardi et al also completed the total synthesis of (-)-233 along with its enantiomer (+)-233 and their C-16 epimers starting from $30 \%$ ee copalic acid ${ }^{[156]}$.

Bioassay-directed separation of the extract from the sponge Thorectandra (unknown species) collected in Papua New Guinea led to the isolation of luffariellolide-type sesterterpenoids, luffariellolide $\mathbf{2 3 4}$ and dehydroluffariellolide diacid $235^{[157]}$. Both compounds had no inhibitory activity against VHR at concentrations as high as $40 \mu \mathrm{g} / \mathrm{mL}$ and they lacked inhibitory selectivity against PTP1B over Cdc25B. The first synthesis of $\mathbf{2 3 4}$ was achieved by a convergent pathway involving $\mathrm{sp}^{3}-\mathrm{sp}^{3}$ cross-coupling and silyloxyfuran oxyfunctionalisation as key steps ${ }^{[158]}$.

Sulfircin 236, a sesterterpene sulfate mentioned at the beginning of this paper, was found to act as a nonspecific PPs inhibitor with moderate PTP1B inhibitory activity $\left(\mathrm{IC}_{50}=29.8\right.$ $\mu \mathrm{mol} / \mathrm{L}$ ) as well as activity against other PTPs (VHR, Cdc25A) with slightly better potencies ${ }^{[16,159]}$ (Figure 14).

\section{Triterpenes}

Five oleanane-type PTP1B inhibitors, including 3a,24dihydroxyolean-12-en-27-oic acid 237, 3-oxoolean-12-en27-oic acid 238, 3 $\beta$-hydroxyolean-12-en-27-oic acid 239 ( $\beta$-peltoboykinolic acid), 33-hydroxyurs-12-en-27-oic acid 240, and $3 \beta, 6 \beta$-dihydroxyolean-12-en-27-oic acid 241 (astilbic acid) were isolated from a $\mathrm{MeOH}$ extract of the rhizomes of the plant Astilbe koreana $a^{[160]}$. Of the isolates, 238 and $\mathbf{2 3 9}$ exhibited the strongest inhibitory activity with $\mathrm{IC}_{50}$ values of $4.9 \pm 0.4$ 
<smiles>CC(C)C(=O)OC[C@H]1C[C@]23CCC4C(C)(C)CCC[C@]4(C)C2CC[C@H]1C3</smiles>

214

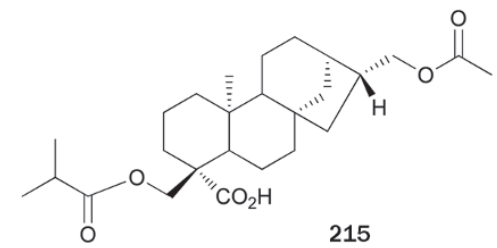

215

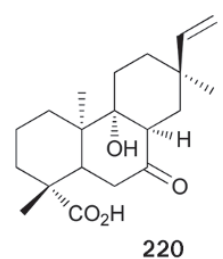

220<smiles>CC(C)CC(=O)OC[C@]1(O)C[C@@]23CCC4[C@@](C)(C(=O)O)CCC[C@@]4(C)C2CC[C@H]1C3</smiles>

224<smiles>Cc1coc2c1C(=O)c1ccc3c(c1C2=O)CCCC3(C)C</smiles>

228

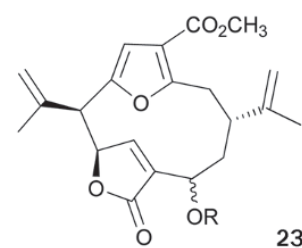

232 R=palmityl<smiles>[R20]C1C2=CC(OC2=O)[C@@H](C(=C)C)c2cc(C(C)=O)c(o2)C[C@H](C(=C)C)[C@@H](O)[C@@H]1O</smiles>

$231 \mathrm{R}=$ palmityl<smiles>C[C@]1(C(=O)O)CCC[C@H]2[C@@H]3CC[C@H](CO)[C@H](CC[C@@]23C)C1</smiles>

216<smiles>C=C[C@]1(C)CC=C2C(CC[C@H]3[C@H]2CCCC3(C)C)C1</smiles>

217

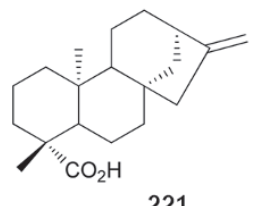

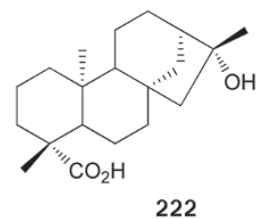

222<smiles>C[C@]12CCC[C@](C)(C(=O)O)C3CC[C@H](C1)[C@@H](CO)CCC32</smiles>

225<smiles>Cc1cccc2c3c(ccc12)C(=O)C1=C(OCC(C)C1)C3=O</smiles>

229<smiles>CC1COC2=C1C(=O)c1ccc3c(c1C2=O)CCCC3(C)C</smiles>

230<smiles>CC(C)C(=O)OC[C@H]1C[C@]23CCC4C(C)(C(=O)O)CCC[C@]4(C)C2CC[C@H]1C3</smiles>

226

Figure 13. Structures of diterpenes 214-232.

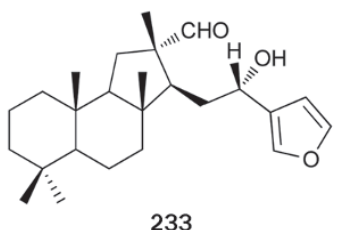

233<smiles>CC1=C(CC/C(C)=C/CC/C(C)=C/CCC2=CC(=O)OC2O)C(C)(C)CCC1</smiles><smiles>CC(=O)C(=CCCC(C)=CCCC(C)=CCCC1=C(C)CCCC1(C)C)C(=O)O</smiles>

235

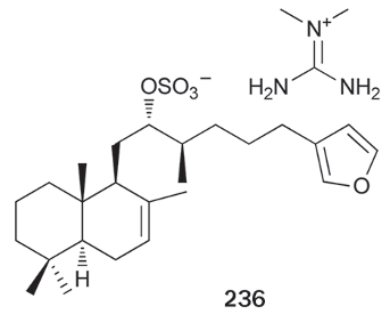

236

Figure 14. Structures of sesterterpenes 233-236.

and $5.2 \pm 0.5 \mu \mathrm{mol} / \mathrm{L}$, respectively. This result indicated that a positional change only of methyl groups at C-29 and C-30 might not affect the inhibitory activity. The preliminary SAR of 238 and 239 with their related synthetic analog indicated that a 3-hydroxyl group and a carboxyl group in this type of triterpenes might be required for activity. Moreover, addition of one more hydroxyl group at C-6 or C-24 may be responsible for a loss of activity.

Three ursane-type triterpenes, ursolic acid 242, corosolic acid 243 and 2a,3a,19a,23-tetrahydroxyurs-12-en-28-oic acid 
244, were isolated from a $\mathrm{MeOH}$ extract of the leaves and stems of the plant Symplocos paniculata using an in vitro PTP1B inhibitory assay ${ }^{[161]}$. Comparison of the activity of triterpenes 242-244 $\left(\mathrm{IC}_{50}\right.$ values of $3.8 \pm 0.5,7.2 \pm 0.8$, and $42.1 \pm 1.5 \mu \mathrm{mol} / \mathrm{L}$, respectively) indicated that the substitution of hydroxyl groups on the ursane-type triterpenes was responsible for the loss of activity. Kinetic studies suggest that $\mathbf{2 4 2}$ is a competitive inhibitor with a $K_{\mathrm{i}}$ value of $2.0 \mu \mathrm{mol} / \mathrm{L}$, whereas 243 is a mixed-type PTP1B inhibitor. Furthermore, ursolic acid 242 was found to stimulate glucose uptake in L6 myotubes and facilitate glucose transporter isoform 4 translocation in $\mathrm{CHO} /$ hIR cells via enhancing IR phosphorylation. Additionally, 242 could inhibit other PTPs, including TCPTP, SHP1, and SHP2 $\left(\mathrm{IC}_{50} \text { values ranging from } 10.50 \pm 0.29 \text { to } 24.56 \pm 0.56 \mu \mathrm{mol} / \mathrm{L}\right)^{[162]}$.

Triterpene metabolites with inhibitory activity, identified as oleanolic acid 245, 33,28-dihydroxy-12-en-olean 246, maslinic acid 247 and $3 \beta$-O-acetyl aleuritolic acid 248, were obtained from the plant Macaranga adenanth $a^{[163]}$. Triterpenes 245-248 showed inhibitory activity with $\mathrm{IC}_{50}$ values ranging from $6.2 \pm 0.9$ to $12.4 \pm 5.5 \mu \mathrm{g} / \mathrm{mL}$. Qian et al designed and synthesized a variety of oleanolic acid $\mathbf{2 4 5}$ derivatives with modified $\mathrm{C}-17$ moieties and rings $\mathrm{A}$ and $\mathrm{C}$. These compounds were PTP1B inhibitors and the bioassay results suggested that the integrity of ring $\mathrm{A}$ and the 12-ene moieties was important in the retention of PTP1B enzyme inhibitory activities. Additionally, hydrophilic and acidic groups as well as the distance between the oleanene and acid moieties were associated with inhibitory activities ${ }^{[164]}$. Preparing a series of derivatives of $\mathbf{2 4 7}$ by introducing various fused heterocyclic rings at the C-2 and C-3 positions, Qiu et al found some derivatives with improved inhibitory activity and selectivity against PTP1B over related PTPs, such as TCPTP, LAR, SHP-1, and SHP-2 ${ }^{[165]}$. The first enantioselective total synthesis of $\mathbf{2 4 5}$ and $\mathbf{2 4 6}$ from 7-methoxy-1-tetraline was reported by Corey et al ${ }^{[166]}$.

Two more PTP1B inhibitors, moronic acid 249 and 250, together with $\mathbf{2 4 2}$ and $\mathbf{2 4 5}$, were purified and characterized from the acetone extract of the leaves and stems of the plant Phoradendron reichenbachianum ${ }^{[167]}$. All isolates were docked with a crystal structure of PTP1B and completely inhibited PTP1B at $50 \mu \mathrm{mol} / \mathrm{L}$. Docking results suggested the potential binding of the triterpenic acids in a binding pocket next to the catalytic site. An extensive hydrogen bond network with the carboxyl group along with Van der Waals interactions stabilized the protein-ligand complexes. The efficient syntheses of 249 and 250 were accomplished starting from betulin $251^{[168,169]}$. Compound 251 from an ethanolic extract of the roots of the plant Euphorbia micractina showed inhibitory activity with an $\mathrm{IC}_{50}$ value of $15.3 \mu \mathrm{mol} / \mathrm{L}$, and a selective cytotoxicity against A2780 ovarian cells ${ }^{[170]}$.

Triterpenes 252-256 were isolated from the stem-bark of the plant Styrax japonica, whose pericarps are used as soap, cough medicine and a piscicidal agent ${ }^{[171]}$. Of the isolates, 253 and $\mathbf{2 5 4}$ exhibited the strongest inhibitory activities with $\mathrm{IC}_{50}$ values of 7.8 and $9.3 \mu \mathrm{mol} / \mathrm{L}$, respectively. Triterpenoid 252, which converted a carbonyl group at C-28 to a hydroxymethyl group, showed weak inhibitory activity $\left(\mathrm{IC}_{50}=44.4 \mu \mathrm{mol} / \mathrm{L}\right)$ compared with 253. Moreover, replacement of a carbonyl group at C-28 to a hydroxyl group $\left(255, \mathrm{IC}_{50}>50 \mu \mathrm{mol} / \mathrm{L}\right)$ and/or a methyl group $\left(256, \mathrm{IC}_{50}>50 \mu \mathrm{mol} / \mathrm{L}\right)$ resulted in the loss of in vitro inhibitory activity. These results also indicated that the C-28 carbonyl group in oleanane-type triterpenoids might be required for PTP1B inhibitory activity.

24-Norursane triterpenes, ilekudinols A 257 and B 258, were isolated as active metabolites from the $\mathrm{MeOH}$ extract of the leaves and stems of the plant Weigela subsessilis ${ }^{[172]}$. Both ilekudinols inhibited PTP1B in a non-competitive manner with $\mathrm{IC}_{50}$ values of $29.1 \pm 2.8$ and $5.3 \pm 0.5 \mu \mathrm{mol} / \mathrm{L}$, respectively. Comparison of the activities of $\mathbf{2 5 7}$ and $\mathbf{2 5 8}$ indicated that the free carboxyl group at C-28 in this type of triterpenes might play a critical role in the inhibition of PTP1B.

Activity-guided fractionation of a $\mathrm{MeOH}$ extract of the roots of the plant $S$ lappa led to the isolation of two active constituents, betulinic acid 259 and betulinic acid methyl ester $2 \mathbf{2 0}^{[138]}$. The bioassay revealed that 259 and 260 inhibited PTP1B activity with $\mathrm{IC}_{50}$ values of $0.70 \pm 0.03$ and $0.93 \pm 0.07 \mu \mathrm{g} / \mathrm{mL}$, respectively. Bioassay-guided fractionation of the $\mathrm{MeOH}$ extract of the stem barks of the plant Sorbus commixta resulted in the isolation of two lupine-type triterpenes, lupenone $\mathbf{2 6 1}$ and lupeol $262^{[173]}$. Both 261 and 262 inhibited PTP1B in a noncompetitive manner with $\mathrm{IC}_{50}$ values of $13.7 \pm 2.1$ and $5.6 \pm 0.9$ $\mu \mathrm{mol} / \mathrm{L}$, respectively. A bioassay for the inhibitory effects on other PPs revealed that $\mathbf{2 6 1}$ and $\mathbf{2 6 2}$ had no inhibitory effects toward VHR and PP1 at levels up to $100 \mu \mathrm{mol} / \mathrm{L}$. Csuk et al developed a practical synthetic route for the synthesis of $\mathbf{2 5 9}$ in one step with a $92 \%$ yield. The synthesis used TEMPO, $\mathrm{NaCl}_{2} \mathrm{O}$ and $\mathrm{NaClO}$ to selectively oxidize the primary alcohol function of $\mathbf{2 5 1}$ without affecting the secondary hydroxyl group ${ }^{[174]}$. A successful multistep enantioselective synthesis of 262 was reported by Surendra et al ${ }^{[175]}$.

Hopane-6a,22-diol 263, a hopane-based triterpene isolated from an $\mathrm{MeOH}$ extract of the Antarctic lichen L carpathica, inhibited PTP1B in a competitive manner with an $\mathrm{IC}_{50}$ value of $3.7 \mu \mathrm{mol} / \mathrm{L}^{[80]}$. Additionally, compound 263 displayed selectivity toward PTP1B over other PTPs, such as TCPTP $\left(\mathrm{IC}_{50}=8.4\right.$ $\mu \mathrm{mol} / \mathrm{L})$, SHP-2 $\left(\mathrm{IC}_{50}>68 \mu \mathrm{mol} / \mathrm{L}\right)$, LAR $\left(\mathrm{IC}_{50}>68 \mu \mathrm{mol} / \mathrm{L}\right)$, and $\mathrm{CD} 45\left(\mathrm{IC}_{50}>68 \mu \mathrm{mol} / \mathrm{L}\right)$ (Figure 15).

The plant Gynostemma pentaphyllum is traditionally used as in Vietnamese folk medicine for the treatment of diabetes. Isolation of the $\mathrm{CHCl}_{3}$-soluble extract of $\mathrm{G}$ pentaphyllum produced dammarne derivatives 264-270, which display inhibitory activity ${ }^{[176]}$. Compound 270 is a 20R epimer of 269 , compounds 264-266 possess an epoxy group, while 267 and 268 possess a side chain of 20S, 23-ene, respectively. Compared with those compounds above, dammarne derivative 269 showed the most potent inhibitory activity $\left(\mathrm{IC}_{50}=5.3 \pm 0.4 \mu \mathrm{mol} / \mathrm{L}\right)$. Additionally, all these isolates showed a very weak inhibitory effect toward VHR with $\mathrm{IC}_{50}$ values of more than $100 \mu \mathrm{mol} / \mathrm{L}$, and kinetic analysis indicated that $\mathbf{2 6 9}$ inhibited PTP1B by a competitive manner $\left(K_{\mathrm{i}}=2.8 \mu \mathrm{mol} / \mathrm{L}\right)$.

\section{Steroids}

Thousands of distinct steroids are found in natural resources. 
<smiles>CC1(C)CC2C3=CCC4C5(C)CCC(=O)C(C)(C)C5CCC4(C)C3(O)CCC2(C)C2CCC1C2(C)C</smiles>

237

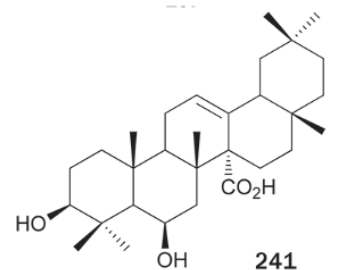

241

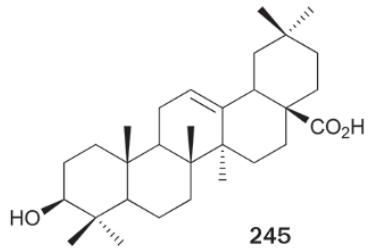

245<smiles>CC1C(=O)CCC2(C)CCC3C4=CC(C)(C)C(O)(O)CCC4C3CCC12</smiles>

249<smiles>CC1(C)CCC2(C)C3CC=C4C5=CCC6C(CC[C@H](O)C6(C)C)C5(C)C4CCC3[C@H]2C1</smiles>

256

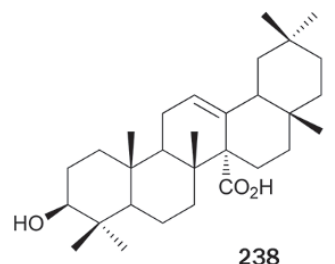

238

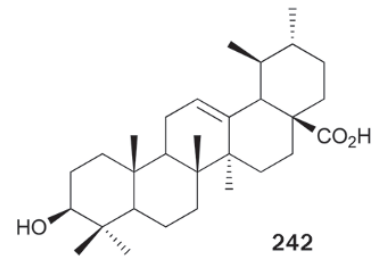

242

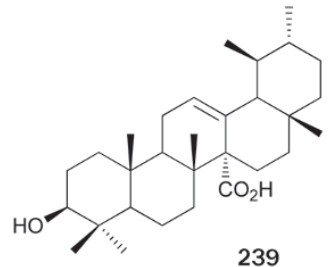

239

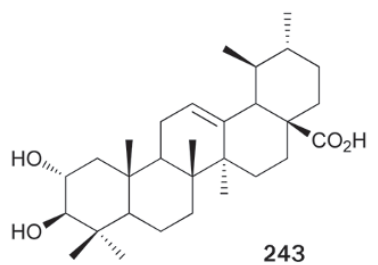

243

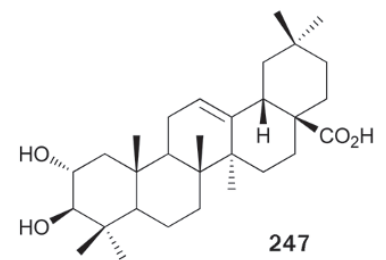

246

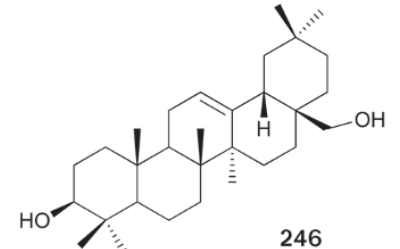

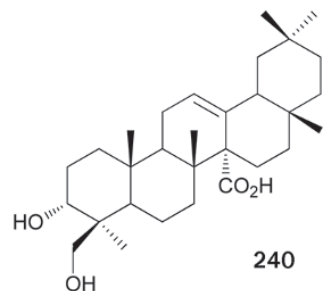

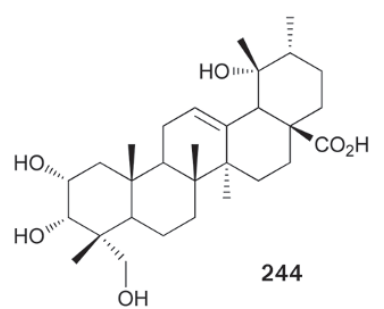

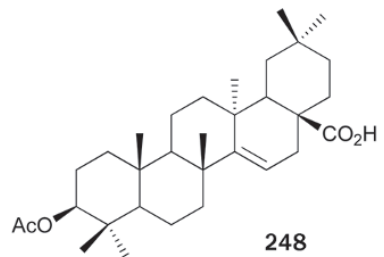<smiles>CC1(C)C=C2C3CCC4C(CCC5C(C)(C)C(O)CCC45C)[C@@H]3CCC2(O)CC1</smiles>

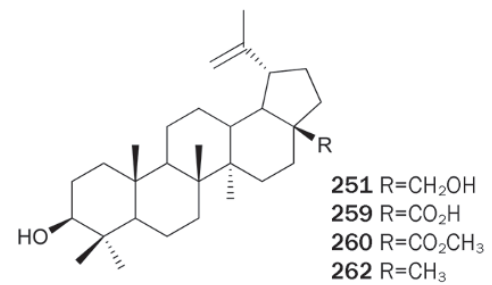

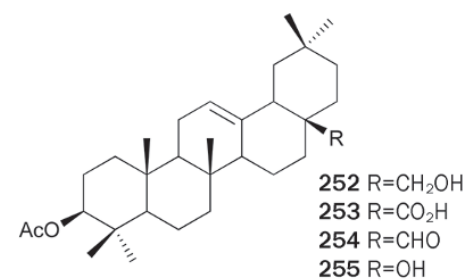

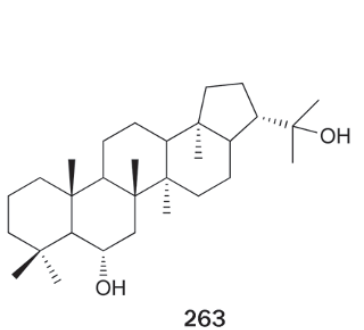

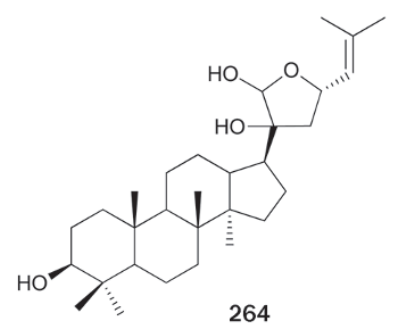

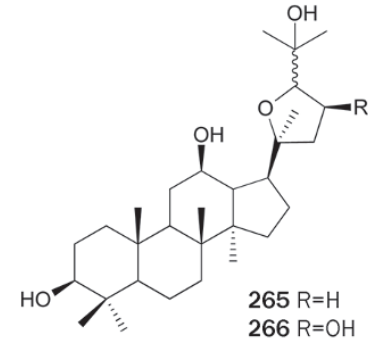

258

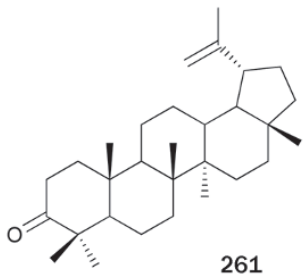

257

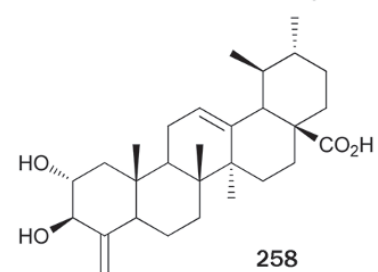

264

$266 \mathrm{R}=\mathrm{OH}$

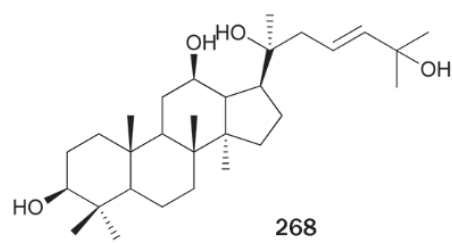

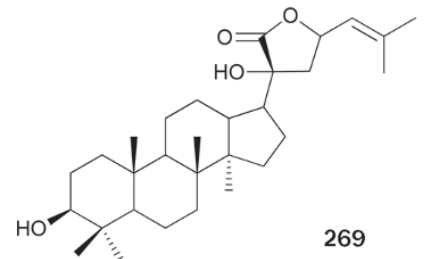

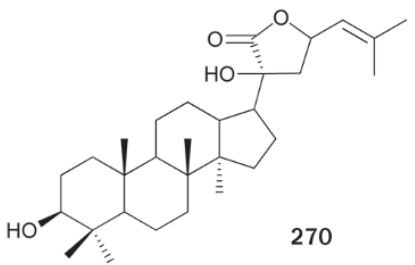

Figure 15. Structures of triterpenes 237-270. 
A variety of steroids play important roles in the life of animals and plants and are extensively used in medicinal chemistry ${ }^{[177]}$. There are also several steroids that act as PTP1B inhibitors.

The $\mathrm{MeOH}$ extract of the sclerotia of the fungus Polyporus umbellatus showed PTP1B inhibitory activity at a level of 30 $\mu \mathrm{g} / \mathrm{mL}$ and produced three steroids $\mathbf{2 7 1 - 2 7 3 ^ { [ 1 7 8 ] }}$. These steroids showed inhibitory activity with $\mathrm{IC}_{50}$ values of $8.9 \pm 0.3$, $6.5 \pm 0.6$, and $7.5 \pm 0.2 \mu \mathrm{g} / \mathrm{mL}$, respectively.

Arenicolsterol A 274, a novel cytotoxic enolic sulphated sterol, was isolated from the marine annelid Arenicola cristata ${ }^{[179]}$. The study of its selectivity on other PTPs indicated that $\mathbf{2 7 4}$ exhibited inhibition on intracellular PTP1B, with a similar potency to Cdc25a, Cdc25b, JSP1, and SHP1, weaker inhibition on mPTPo, TCPTP, and PTP-PEST, and almost no inhibition on receptor-like PTP-LAR and PTPa. The reduction in apoptosis of HeLa cells caused by $\mathbf{2 7 4}$ was found to be correlative with the inhibition of the PTPs.

Phytochemical investigation on the stem bark of the plant Toona ciliata var pubescens produced (Z)-aglawone $275^{[180]}$. (Z)aglawone 275 inhibited PTP1B in a competitive manner with an $\mathrm{IC}_{50}$ value of $1.12 \mu \mathrm{g} / \mathrm{mL}$. It is interesting to note that the (E)-isomer of $\mathbf{2 7 5}$ showed no inhibition of PTP1B.

Calicoferol E 276, a secosterol isolated from the gorgonian Muricella sinensis collected from the South China Sea, exhibited inhibitory activity with an $\mathrm{IC}_{50}$ value of $27.28 \mu \mathrm{mol} / \mathrm{L}^{[181]}$. Compound $\mathbf{2 7 6}$ has been synthesized via a concise linear synthesis ${ }^{[182]}$. Key steps of the synthetic process included the preparation of 9a-hydroxycholest-1,4-diene-3-one from commercially available $5 a$-cholestan- $3 \beta$-ol followed by acidcatalyzed rearrangement (Figure 16).

\section{$\mathrm{N}$ - or S-containing compounds}

Acylic manoalide derivatives, hippolides A 277 and B 278, were isolated from the sponge Hippospongia lachne of the South China Sea. Their absolute configurations were established by the modified Mosher's method and CD data ${ }^{[183]}$. Both hippolides exhibited inhibitory activity with $\mathrm{IC}_{50}$ values of 23.81 and $39.67 \mu \mathrm{mol} / \mathrm{L}$, respectively, and showed moderate cytotoxicity against HCT-116 cell lines. Additionally, hippolides A 277 showed weak anti-inflammatory activity.

Caulerpin 279, an indole derivative isolated from the Chinese green alga Caulerpa taxifolia, showed inhibitory activity with an $\mathrm{IC}_{50}$ value of $3.77 \mu \mathrm{mol} / \mathrm{L}^{[184]}$. Three 3-bromoamino-7bromomethylnaphthalene analogs 280-282, isolated from the red alga $L$ similis, showed weak inhibitory activity with $\mathrm{IC}_{50}$ values ranging from 65.3 to $102 \mu \mathrm{mol} / \mathrm{L}^{[73]}$.

Berberine $\mathbf{2 8 3}$ is an isoquinoline alkaloid of wide distribution in nature ${ }^{[185]}$ that is widely used in traditional eastern homeotherapy, particularly in treating gastrointestinal infections and as an anti-hyperglycemic agent by many Chinese physicians ${ }^{[186]}$. In docking experiments, compound 283 was found to fit readily within the binding pocket of PTP1B in a low energy orientation and to potently and competitively inhibit recombinant PTP1B in vitro $\left(K_{\mathrm{i}}=91.3 \mathrm{nmol} / \mathrm{L}\right)$. This finding suggests at least one of the reasons for the reported anti-hyperglycemic activities of berberine ${ }^{[186]}$. Additionally, compound 283 demonstrated insulin-mimicry effects on both adipocytes and myocytes, which may occur through the inhibition of PTP1B activity (inhibitory activity up to $40 \%$ and $60 \%$ at 50 and $100 \mu \mathrm{mol} / \mathrm{L}$, respectively) ${ }^{[187]}$.

Papaverine 284, found in the opium poppy, is an opium alkaloid used primarily in the treatment of visceral spasm, vasospasm (especially those involving the heart and the brain), and occasionally in the treatment of erectile dysfunction ${ }^{[188]}$. Inspired by the structural similarity with 283 , papaverine 284 was inferred to exhibit inhibitory activity. It was shown that 284 readily docked within the binding pocket of PTP1B in a low-energy orientation via an optimal set of attractive interactions ${ }^{[189]}$. Compound 284 exhibited a potent in vitro inhibitory effect $\left(\mathrm{IC}_{50}=1.20 \mu \mathrm{mol} / \mathrm{L}\right)$, and significantly decreased fasting blood glucose levels of Balb/c mice in vivo.

Ceramide 285, determined to be a $\mathrm{C}_{23}$-phytosphingosineing unit containing three hydroxyl groups and $\mathrm{C}_{19}$-fatty acid, was isolated from a $\mathrm{MeOH}$ extract of the sclerotia of the fungus $P$ umbellatus ${ }^{[178]}$. This compound showed inhibitory activity with an $\mathrm{IC}_{50}$ value of $25.1 \pm 0.1 \mu \mathrm{mol} / \mathrm{L}$. Albidopyrone 286, a a-pyrone-containing secondary metabolite isolated from the fungus Streptomyces albidoflavus, exhibited weak inhibitory activity $^{[190]}$. A macrolactam polyketide antibiotic, piceamycin 287 was isolated from the extract of the fungus Streptomyces (unknown species) found in the mycorrhizosphere of the Norway spruce. Compound 287 showed inhibitory activity with an $\mathrm{IC}_{50}$ value of $10.1 \mu \mathrm{mol} / \mathrm{L}$ as well as antitumor and antifungal activities ${ }^{[191]}$. Stereocalpin A 288, a unique cyclic peptide incorporating a 5-hydroxy-2,4-dimethyl-3-oxo-octanoic acid in the structure, was isolated from the $\mathrm{MeOH}$ extract of the Antarctic lichen $S$ alpinum ${ }^{[192]}$. Compound 288 inhibited PTP1B with an $\mathrm{IC}_{50}$ value of $40 \mu \mathrm{mol} / \mathrm{L}$ and showed moderate cytotoxicity against three human solid tumor cell lines, including HT-29, B16/F10 and HepG2. However, the spectral data

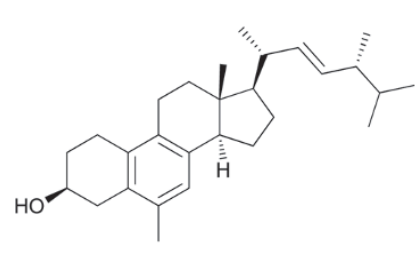

271

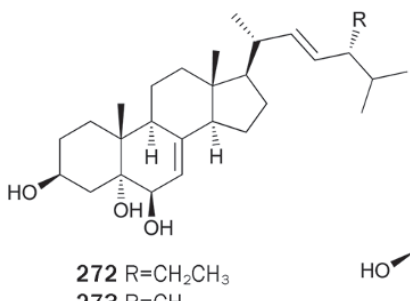

$273 \mathrm{R}=\mathrm{CH}_{3}$

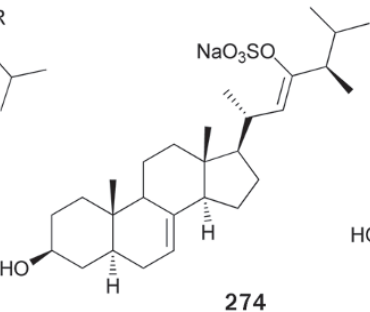

274

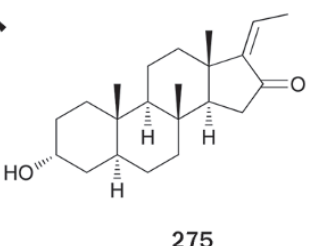

275

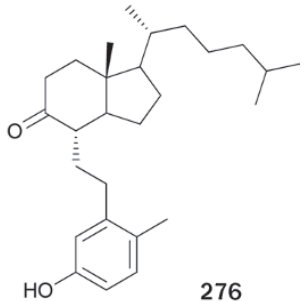

Figure 16. Structures of steroids 271-276. 
of synthetic $\mathbf{2 8 8}$ did not match with the data reported for the naturally derived $\mathbf{2 8 8}$, suggesting that the structure of natural 288 had been assigned incorrectly ${ }^{[193]}$.

Two 17-membered carbocyclic tetraenes, chejuenolides A 289 and B 290, were isolated from the EtOAc extract of the marine bacteria Hahella chejuensis and their absolute configurations were assigned by application of modified Mosher method $^{[194]}$. Both chejuenolides showed weak inhibitory activity $(65 \%$ and $75 \%$ at a concentration of $150 \mu \mathrm{g} / \mathrm{mL}$, respectively) (Figure 17).

Gymnorrhizol 291, a novel, unusual 15-membered macyrocylic polydisulfide with an unprecedented carbon skeleton composed of three repeated 1,3-dimercaptopropan2-ol units, was isolated from the Chinese mangrove Brugiera gymnorrhiza ${ }^{[195]}$. Its structure was determined by extensive spectroscopic studies and further confirmed by X-ray crystallographic analysis ${ }^{[196]}$. Compound 291 exhibited inhibitory activity with an $\mathrm{IC}_{50}$ value of $14.9 \mu \mathrm{mol} / \mathrm{L}$. Its total synthesis was achieved in only three steps with a $25 \%$ overall yield ${ }^{[197]}$.
Further research on the chemical constituents of B gymnorrhiza collected from Guangdong Province, China, led to the isolation of bruguiesulfurol 292, an analog of 291. Compound 292 inhibited PTP1B with an $\mathrm{IC}_{50}$ value of $17.5 \mu \mathrm{mol} / \mathrm{L}^{[198]}$.

\section{Miscellaneous}

RK-682 293 (3-hexadecanoyl-5-hydroxymethyl tetronic acid), isolated from the fungus Streptomyces (unknown species), was originally found to be a potent inhibitor of tyrosine phosphatease $^{[199]}$ and was therefore used as a positive control in PTP1B inhibitory activity assays $\left(\mathrm{IC}_{50}=4.5 \pm 0.5 \mu \mathrm{mol} / \mathrm{L}\right)^{[66]}$. Early stereoselective syntheses by Sodeoka et al ${ }^{[200]}$ and others $^{[201,202]}$ served to ascertain the absolute configuration of 293. Recently, 293 was prepared in solution and on a solid support from (2R)-glycerates in five steps with a yield of approximately $40 \%{ }^{[203]}$. A chemical constituent study of $S$ griseoruber produced an a-pyrone-containing secondary metabolite, BE 51068 294, with weak inhibitory activity ${ }^{[204]}$. Dihydrocarolic acid 295 and penitricin D 296, isolated from a fermentation

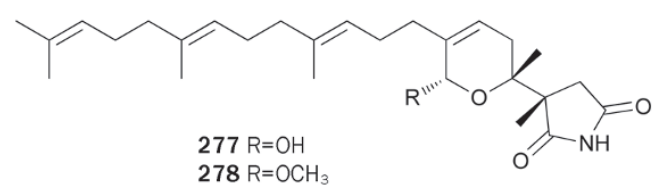<smiles>COc1ccc2cc3[n+](cc2c1OC)CCc1cc2c(cc1-3)OCO2</smiles>

283<smiles>COc1ccc(Cc2nccc3cc(OC)c(OC)cc23)cc1OC</smiles>

284<smiles>CC(=O)C1=Cc2c(c(C(C)=O)cc3[nH]c4ccccc4c23)Nc2ccccc21</smiles>

279<smiles>CCNCCC[C@H](O)C(=O)N[C@@H](CO)[C@H](O)[C@H](O)NCC</smiles><smiles>[R]c1c(CBr)c([R3])c2c(Br)c(Br)c(NBr)cc2c1Br</smiles>

$280 \mathrm{R}_{1}=\mathrm{Br}, \mathrm{R}_{2}=\mathrm{H}, \mathrm{R}_{3}=\mathrm{H}$ $281 \mathrm{R}_{1}=\mathrm{H}, \mathrm{R}_{2}=\mathrm{H}, \mathrm{R}_{3}=\mathrm{Br}$ $282 \mathrm{R}_{1}=\mathrm{H}, \mathrm{R}_{2}=\mathrm{Br}, \mathrm{R}_{3}=\mathrm{H}$

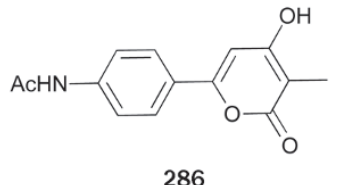<smiles>C/C=C\C=C/C(C)CNC(=O)/C=C/C=C\C=C\C=C\C(=O)C1=C(O)C(=O)CC1(C)C</smiles>

287

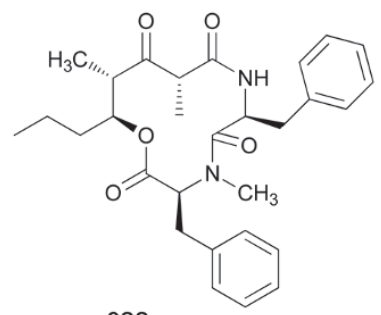

288<smiles>CC(=O)N[C@H](/C=C(C)/C=C/[C@H](O)C/C=C(C)/C=C/[C@@H](O)C/C=C(\C)C(=O)C(C)C(C)C)C(C)C</smiles>

289<smiles>C/C=C(\C)C(=O)/C(C)=C/C[C@@H](O)/C=C/C(C)=C/C[C@H](O)C/C=C/C(C)=C/[C@H](NC(C)=O)C(C)C</smiles>

290<smiles>OC1CSSCC(O)CSSC(O)CSSC1</smiles>

291

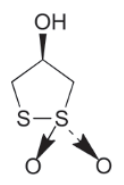

292

Figure 17. Structures of N- or S-containing compounds 277-292. 
broth of the fungus Aspergillus niger, inhibited PTP1B with $\mathrm{IC}_{50}$ values of 38.0 and $15.8 \mu \mathrm{mol} / \mathrm{L}$, respectively ${ }^{[205]}$. Both compounds 295 and 296 also exhibited a dose-dependent inhibition of CD45. Ascochitine 297, a polyketide isolated from the marine-derived fungus Ascochyta salicorniae, was found to inhibit PTP1B with an $\mathrm{IC}_{50}$ value of $38.5 \pm 6.5 \mu \mathrm{mol} / \mathrm{L}^{[206]}$. Compound 297 was also active against other PPs, such as Cdc25a and MPtpB, but inactive against VHR, MPtpA, and VE-PTP. The first total synthesis of $\mathbf{2 9 7}$ was reported by Galbraith et al in $1966^{[207]}$.

Research on the chemical constituents of the Chinese mangrove Aegiceras corniculatum led to the isolation of falcarindiol 298, which showed inhibitory activity with an $\mathrm{IC}_{50}$ value of $9.15 \pm 2.48 \mu \mathrm{mol} / \mathrm{L}^{[208]}$. Zheng et al reported the first stereoselective synthesis of $\mathbf{2 9 8}$ from $L$-tartaric acid and $D$-xylose via the Cadiot-Chodkiczwicz reaction as a key step ${ }^{[209]}$. Further synthetic studies have reported several strategies for the stereoselective synthesis of $28^{[210-212]}$.

Further research on the chemical constituents of the EtOH extract of the plant Ardisia japonica by Li et al led to the isolation of $[1,4]$ benzoquinones 299-302 $2^{[213]}$. Benzoquinones 299302 showed significant in vitro inhibitory activities with $\mathrm{IC}_{50}$ values ranging from $3.01 \pm 0.9$ to $19.15 \pm 1.0 \mu \mathrm{mol} / \mathrm{L}$. Because 299-302 have the same substituted [1,4]benzoquinone skeleton and length of the aliphatic side chain at C-3, it seems that nonpolar 5-O-substituents increase inhibitory activity. In 1992, Yadav et al reported a practical route for preparing 299 from 3-bromo-4-hydroxy-5-methoxybenzaldehyde ${ }^{[214]}$. Later, two synthetic routes for the preparation of $\mathbf{2 9 9}$ were reported by Poigny et al and Pfeifer et al, respectively ${ }^{[215,216]}$.

A naphthoquinone derivative, cyclonoside A 303, was iso-

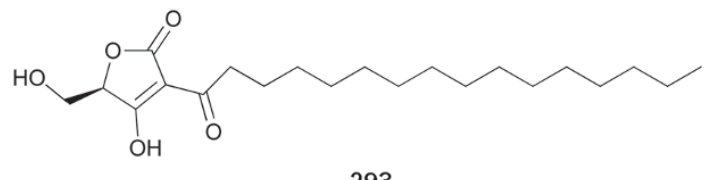

293

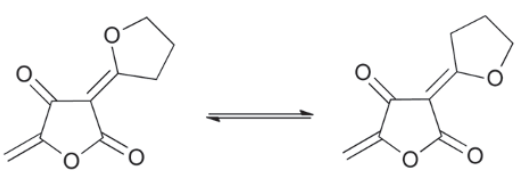

295
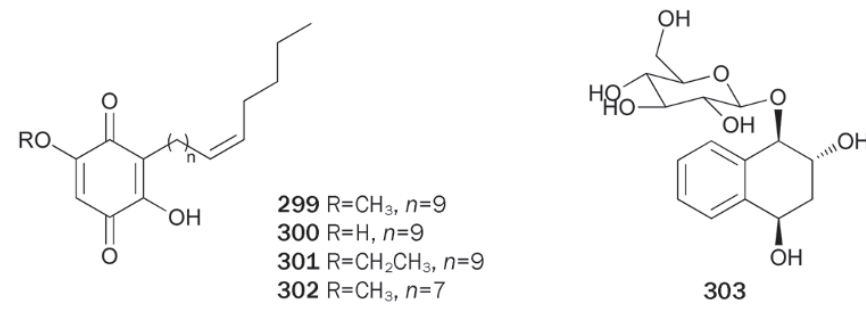

303 lated from the leaves of the plant $C$ paliurus. The absolute configuration of $\mathbf{3 0 3}$ was determined by $\mathrm{X}$-ray analysis. This compound showed inhibition of PTP1B with an $\mathrm{IC}_{50}$ value of $2.11 \pm 0.66 \mu \mathrm{mol} / \mathrm{L}^{[35]}$. Research on an extract of the Okinawan sponge Plakortis (unknown species) led to the isolation of manzamenones B $\mathbf{3 0 4}$ and E 305, which are fatty acid derivatives possessing a bicycle $[4,3,0]$ nonane skeketon ${ }^{[217]}$. Both manzamenones exhibited inhibitory activity with $\mathrm{IC}_{50}$ values of 10.8 and $13.5 \mu \mathrm{mol} / \mathrm{L}$, respectively ${ }^{[218]}$ (Figure 18).

\section{Conclusions}

Much research has established PTP1B inhibitors as potential therapeutic options for the treatment of type 2 diabetes and obesity. Research has led to the development of approximately 300 PTP1B inhibitors isolated from a variety of natural resources, which have been reviewed here in detail. Many of these inhibitors have promising in vivo activities and selectivity profiles. These inhibitors should be considered for development as promising clinical drug candidates or drugs.

For example, in the group of phenolics, compounds 24 and 25 showed potent anti-hyperglycemic activity in the STZinduced diabetic rats and $\mathrm{db} / \mathrm{db}$ mouse models. Compound 75 exhibited inhibition on PTP1B without cytotoxicity against $\mathrm{CHO}$ cells at concentrations greater than $20 \mu \mathrm{mol} / \mathrm{L}$ for $48 \mathrm{~h}$. Compounds 94, 96, 99, and 101 showed PTP1B inhibitory activity and strong in vitro anticancer activity against an array of cancer cells. Compounds 116-118 showed good selectivity over other PPs. The preliminary SAR of some flavonoids suggests that less polar substituents (eg, isoprenyl group, methylation or aceylation of hydroxyl group) on their skeletons are usually beneficial to activity, while addition of one<smiles>COc1c(C)c(C/C=C(C)/C=C/C=C/c2ccc(C)cc2/C=C/CO)oc(=O)c1C</smiles><smiles>CCC(C)c1occ2c(=O)c(C(=O)O)c(O)cc-2c1C</smiles>

297<smiles>C=CC(O)C#CC#CC(O)/C=C\CC</smiles>

298
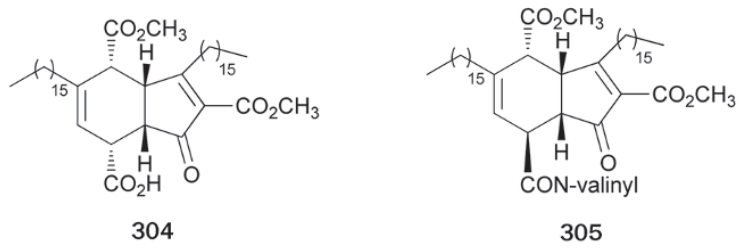

305

Figure 18. Structures of miscellaneous 293-305. 
hydroxyl group may lead to decreased activity. According to these results, various series of flavonoid PTP1B inhibitors with different substituents on the aromatic rings should be synthesized and evaluated to find PTP1B inhibitors with better activities and selectivity profiles. Moreover, the flavonoid skeleton is easily synthesized, providing many opportunities for medicinal chemists to carry out detailed SAR studies. Additionally, flavonoids are abundant in many foods (eg, fruits or vegetable) and usually have antiviral, antitumor, antiplatelet, anti-inflammatory or antioxidant activities, which makes them a preferred scaffold with favorable properties for drug design. Other phenolics also exhibited good activity profiles. For example, bromophenols 120-123 might be responsible for the in vivo anti-hyperglycemic activity of the extract from red alga. Phenolic acids 149, 150, 152, 184 also showed good selectivity over other PPs.

In the terpene group, diterpene $\mathbf{2 1 4}$ and its isobutyryloxy derivate 215 exhibited inhibition on PTP1B without inhibitory effects toward VHR and PP1. Compounds 231 and 232 are inactive against PTPs, such as LAR, SHP-1, and MKPX. The preliminary SAR for kaurane-type diterpene PTP1B inhibitors suggests that an ester moiety at C-17 position, such as isobutyryloxy group, is essential for activity. Additionally, the hydroxyl group substituent at the C-17 or C-16 position usually decreases activity. Some important triterpene PTP1B inhibitors, such as 245, 247, and 269, are widely distributed in food and medicinal plants. Additionally, compound $\mathbf{2 4 5}$ is relatively non-toxic, hepatoprotective, and exhibits antitumor and antiviral properties. Currently, many studies on the structural modification of this class of PTP1B inhibitors have been performed by several research groups. The SAR information obtained is very helpful for the design of triterpene-type antidiabetic drug candidates.

Most of the pharmaceuticals currently on the market are $\mathrm{N}$-containing compounds, so the finding that alkaloid drugs (eg, berberine $\mathbf{2 8 3}$ and papaverine 284) have inhibitory activity on PTP1B is very important and positive to design new $\mathrm{N}$-containing PTP1B inhibitors. Moreover, the rare natural polydisulfides 291 and 292 represent a group of PTP1B inhibitors with an unusual carbon skeleton. These compounds provide a new chemical molecular template for designing novel anti-diabetic drug candidates. More synthetic and pharmacologic studies on this type of compounds are needed to obtain detailed SAR information.

As presented above, although many natural PTP1B inhibitors exhibit promising clinical potential, to the best of our knowledge there are no clinically used PTP1B inhibitors approved by the FDA for use in the USA, which is most likely due to relatively low activities (micromole level for $\mathrm{IC}_{50}$ ) or lack of selectivity. Designing more drug-like PTP1B inhibitors as oral agents is a challenging task for two reasons. The first reason is the highly charged nature of the catalytic domain of PTP1B. The other reason is the structural homogeneity of the active and secondary binding sites in PTPs, which leads to a lack of targeting selectivity. However, it is very important to note that many of the natural PTP1B inhibitors, summarized herein, possess fascinating molecular architectures, potent activity, and better PTP1B selectivity. These compounds could be developed as anti-diabetic drugs or at least promising drug candidates in the near future. Additionally, the information provided herein is helpful for designing and synthesizing new PTP1B inhibitors. With the ongoing efforts and interest from chemists and pharmacologists, it is highly probable that more potent and selective PTP1B inhibitors will emerge, either directly from natural resources or derived from the structural optimization of natural products.

\section{Acknowledgements}

This work was supported financially by National Marine "863" Project (No 2011AA09070102), Natural Science Foundation of China (No 31070310, 40976048, 21021063, 21072204, and 81072572), the SKLDR/SIMM Projects (№ SIMM1203ZZ-03 and SIMM1105KF-04), and was partially funded by National S\&T Major Projects (№ 2011ZX09307-002-03), and the EU 7th Framework Programme-IRSES Project (2010-2014).

\section{Supplementary information}

Supplementary data (names, PTP1B inhibitory activity data, source species, and references of compounds 1-305) associated with this article are available at website of Acta Pharmacologica Sinica on NPG.

\section{References}

1 WHO. Diabetes. Available from: http://www.who.int/mediacentre/ factsheets/fs312/en/index.html.

2 Eberhardt MS, Ogden C, Engelgau M, Cadwell B, Hedley AA, Saydah $\mathrm{SH}$. Prevalence of overweight and obesity among adults with diagnosed diabetes - United States, 1988--1994 and 1999-2002. MMWR 2004; 53: 1066-8.

3 Risérus U, Willett WC, Hu FB. Dietary fats and prevention of type 2 diabetes. Prog Lipid Res 2009; 48: 44-51.

4 Newman DJ, Cragg GM. Natural products as sources of new drugs over the last 25 years. J Nat Prod 2007; 70: 461-77.

5 Jung $M$, Park M, Lee HC, Kang YH, Kang ES, Kim SK. Antidiabetic agents from medicinal plants. Curr Med Chem 2006; 13: 1203-18.

6 Zhang S, Zhang ZY. PTP1B as a drug target: recent developments in PTP1B inhibitor discovery. Drug Discov Today 2007; 12: 373-81.

7 Alonso A, Sasin J, Bottini N, Friedberg I, Friedberg I, Osterman A, et al. Protein tyrosine phosphatases in the human genome. Cell 2004; 117: 699-711.

8 Lessard L, Stuible M, Tremblay ML. The two faces of PTP1B in cancer. Biochim Biophys Acta 2010; 1804: 613-9.

9 Combs AP. Recent advances in the discovery of competitive protein tyrosine phosphatase $1 \mathrm{~B}$ inhibitors for the treatment of diabetes, obesity, and cancer. J Med Chem 2010; 53: 2333-44.

10 Nichols AJ, Mashal RD, Balkan B. Toward the discovery of small molecule PTP1B inhibitors for the treatment of metabolic diseases. Drug Dev Res 2006; 67: 559-66.

11 Taylor SD, Hill B. Recent advances in protein tyrosine phosphatase 1B inhibitors. Expert Opin Invest Drugs 2004; 13: 199-214.

12 Taylor SD. Inhibitors of protein tyrosine phosphatase 1B (PTP1B). Curr Top Med Chem 2003; 3: 759-82.

13 Lee S, Wang Q. Recent development of small molecular specific inhibitor of protein tyrosine phosphatase 1B. Med Res Rev 2007; 27: 
553-73.

14 Mohler ML, He Y, Wu Z, Hwang DJ, Miller DD. Recent and emerging anti-diabetes targets. Med Res Rev 2009; 29: 125-95.

15 Thareja S, Aggarwal S, Bhardwaj TR, Kumar M. Protein tyrosine phosphatase 1B inhibitors: A molecular level legitimate approach for the management of diabetes mellitus. Med Res Rev 2012; 32: 459-517.

16 Cebula RE, Blanchard JL, Boisclair MD, Pal K, Bockovich NJ. Synthesis and phosphatase inhibitory activity of analogs of sulfircin. Bioorg Med Chem Lett 1997; 7: 2015-20.

17 Chen RM, Hu LH, An TY, Li J, Shen Q. Natural PTP1B inhibitors from Broussonetia papyrifera. Bioorg Med Chem Lett 2002; 12: 3387 90.

18 Zhang ZY. Protein-tyrosine phosphatases: Biological function, structural characteristics, and mechanism of catalysis. Crit Rev Biochem Mol Biol 1998; 33: 1-52.

19 Wang WQ, Sun JP, Zhang ZY. An overview of the protein tyrosine phosphatase superfamily. Curr Top Med Chem 2003; 3: 739-48.

20 Barford D, Flint AJ, Tonks NK. Crystal structure of human protein tyrosine phosphatase 1B. Science 1994; 263: 1397-404.

21 Zhang ZY, Maclean D, McNamara DJ, Sawyer TK, Dixon JE. Protein tyrosine phosphatase substrate specificity: size and phosphotyrosine positioning requirements in peptide substrates. Biochemistry 1994; 33: 2285-90.

22 Palmer ND, Bento JL, Mychaleckyj JC, Langefeld CD, Campbell JK, Norris JM, et al. Association of protein tyrosine phosphatase $1 \mathrm{~B}$ gene polymorphisms with measures of glucose homeostasis in Hispanic Americans: the insulin resistance atherosclerosis study (IRAS) family study. Diabetes 2004; 53: 3013-9.

23 Elchebly M, Payette P, Michaliszyn E, Cromlish W, Collins S, Loy AL, et al. Increased insulin sensitivity and obesity resistance in mice lacking the protein tyrosine phosphatase-1B gene. Science 1999; 283: 1544-8.

24 Klaman LD, Boss O, Peroni OD, Kim JK, Martino JL, Zabolotny JM, et al. Increased energy expenditure, decreased adiposity, and tissue-specific insulin sensitivity in protein-tyrosine phosphatase 1B-deficient mice. Mol Cell Biol 2000; 20: 5479-89.

25 Cheng A, Uetani N, Simoncic PD, Chaubey VP, Lee-Loy A, McGlade CJ, et al. Attenuation of leptin action and regulation of obesity by protein tyrosine phosphatase 1B. Dev Cell 2002; 2: 497-503.

26 Xie L, Lee SY, Andersen JN, Waters S, Shen K, Guo XL, et al. Cellular effects of small molecule PTP1B inhibitors on insulin signaling. Biochemistry 2003; 42: 12792-804.

27 Crozier A, Jaganath IB, Clifford MN. Dietary phenolics: chemistry, bioavailability and effects on health. Nat Prod Rep 2009; 26: 100143.

28 Veitch NC, Grayer RJ. Flavonoids and their glycosides, including anthocyanins. Nat Prod Rep 2011; 28: 1626-95.

29 Yoon G, Lee W, Kim SN, Cheon SH. Inhibitory effect of chalcones and their derivatives from Glycyrrhiza inflata on protein tyrosine phosphatase 1B. Bioorg Med Chem Lett 2009; 19: 5155-7.

30 Jeon JH, Kim MR, Jun JG. Concise synthesis of licochalcone A through water-accelerated [3,3]-sigmatropic rearrangement of an aryl prenyl ether. Synthesis 2011; 2011: 370-6.

31 Nielsen SF, Chen M, Theander TG, Kharazmi A, Christensen SB. Synthesis of antiparasitic licorice chalcones. Bioorg Med Chem Lett 1995; 5: 449-52.

$32 \mathrm{Na} \mathrm{Y,} \mathrm{Cha} \mathrm{JH,} \mathrm{Yoon} \mathrm{HG,} \mathrm{Kwon} \mathrm{Y.} \mathrm{A} \mathrm{concise} \mathrm{synthesis} \mathrm{of} \mathrm{licochalcone}$ $\mathrm{E}$ and its regio-isomer, licochalcone F. Chem Pharm Bull 2009; 57: 607-9.

33 Li S, Li W, Wang Y, Asada Y, Koike K. Prenylflavonoids from Glycyr- rhiza uralensis and their protein tyrosine phosphatase-1B inhibitory activities. Bioorg Med Chem Lett 2010; 20: 5398-401.

34 Hoang DM, Ngoc TM, Dat NT, Ha DT, Kim YH, Luong HV, et al. Protein tyrosine phosphatase $1 \mathrm{~B}$ inhibitors isolated from Morus bombycis. Bioorg Med Chem Lett 2009; 19: 6759-61.

35 Zhang J, Shen Q, Lu JC, Li JY, Liu WY, Yang JJ, et al. Phenolic compounds from the leaves of Cyclocarya paliurus (Batal.) ljinskaja and their inhibitory activity against PTP1B. Food Chem 2010; 119: 1491-6.

36 Wagner H, Danninger H, Seligmann O, Farkas L. Synthese von glucuroniden der flavonoid-reihe, I. Erste synthese eines natürlich vorkommenden flavonoid-glucuronids (quercetin-3- $\beta$ - $D$-glucuronid). Chem Ber 1970; 103: 3674-7.

37 Min BS. Revision of structures of flavanoids from Scutellaria indica and their protein tyrosine phosphatase $1 \mathrm{~B}$ inhibitory activity. Nat Prod Sci 2006; 12: 205-9.

38 Huang WH, Chien PY, Yang $\mathrm{CH}$, Lee AR. Novel synthesis of flavonoids of Scutellaria baicalensis Georgi. Chem Pharm Bull 2003; 51: 33940.

39 Lee MS, Kim CH, Hoang DM, Kim BY, Sohn CB, Kim MR, et al. Genistein-derivatives from Tetracera scandens stimulate glucoseuptake in L6 myotubes. Biol Pharm Bull 2009; 32: 504-8.

40 Rao KSRM, Iyer CSR, Iyer PR. Synthesis of alpinum isoflavone, derrone and related pyranoisoflavones. Tetrahedron 1987; 43: 3015-9.

41 Punitha R, Manoharan S. Antihyperglycemic and antilipidperoxidative effects of Pongamia pinnata (Linn.) Pierre flowers in alloxan induced diabetic rats. J Ethnopharmacol 2006; 105: 39-46.

42 Tamrakar AK, Yadav PP, Tiwari P, Maurya R, Srivastava AK. Identification of pongamol and karanjin as lead compounds with antihyperglycemic activity from Pongamia pinnata fruits. J Ethnopharmacol 2008; 118: 435-9.

43 Goel A, Dixit M. Amberlyst 15-catalyzed efficient synthesis of 5-acetyl-4-hydroxy-coumarone and 5-acetyl-6-hydroxy-coumarone: Crucial precursors for several naturally occurring furanoflavones. Synlett 2004; 2004: 1990-4.

44 Yadav PP, Ahmad G, Maurya R. An efficient route for commercially viable syntheses of furan- and thiophene-anellated $\beta$-hydroxychalcones. Tetrahedron Lett 2005; 46: 5621-4.

45 Hossain MA, Das AK, Salehuddin SM. Synthesis of karanjin, naturally occurring furanoflavone. Pak J Sci Ind Res 2003; 46: 31-2.

46 Bae EY, Na M, Njamen D, Mbafor JT, Fomum ZT, Cui L, et al. Inhibition of protein tyrosine phosphatase $1 \mathrm{~B}$ by prenylated isoflavonoids isolated from the stem bark of Erythrina addisoniae. Planta Med 2006; 72: 945-8.

$47 \mathrm{Na}$ M, Jang J, Njamen D, Mbafor JT, Fomum ZT, Kim BY, et al. Protein tyrosine phosphatase-1B inhibitory activity of isoprenylated flavonoids isolated from Erythrina mildbraedii. J Nat Prod 2006; 69: 1572-6.

48 Jang J, Na M, Thuong PT, Njamen D, Mbafor JT, Fomum ZT, et al. Prenylated flavonoids with PTP1B inhibitory activity from the root bark of Erythrina mildbraedii. Chem Pharm Bull 2008; 56: 85-8.

49 Cui L, Ndinteh DT, Na M, Thuong PT, Silike-Muruumu J, Njamen D, et al. Isoprenylated flavonoids from the stem bark of Erythrina abyssinica. J Nat Prod 2007; 70: 1039-42.

50 Cui L, Thuong PT, Lee HS, Ndinteh DT, Mbafor JT, Fomum ZT, et al. Flavanones from the stem bark of Erythrina abyssinica. Bioorg Med Chem 2008; 16: 10356-62.

51 Cui L, Lee HS, Ndinteh DT, Mbafor JT, Kim YH, Le TVT, et al. New prenylated flavanones from Erythrina abyssinica with protein tyrosine phosphatase 1B (PTP1B) inhibitory activity. Planta Med 2010; 76: 
713-8.

52 Nguyen PH, Dao TT, Kim J, Phong DT, Ndinteh DT, Mbafor JT, et al. New 5-deoxyflavonoids and their inhibitory effects on protein tyrosine phosphatase 1B (PTP1B) activity. Bioorg Med Chem 2011; 19: 3378-83.

53 Nguyen PH, Le TV, Thuong PT, Dao TT, Ndinteh DT, Mbafor JT, et al. Cytotoxic and PTP1B inhibitory activities from Erythrina abyssinica. Bioorg Med Chem Lett 2009; 19: 6745-9.

54 Dao TT, Nguyen PH, Thuong PT, Kang KW, Na M, Ndinteh DT, et al. Pterocarpans with inhibitory effects on protein tyrosine phosphatase 1B from Erythrina lysistemon Hutch. Phytochemistry 2009; 70 : 2053-7.

$55 \mathrm{Na}$ M. Inhibitory effect of constituents from Cercis chinensis on cellular aging [dissertation]. Daejeon, Korea: Chungnam National University; 2004. 114 p.

56 Farmer RL, Biddle MM, Nibbs AE, Huang X, Bergan RC, Scheidt KA. Concise syntheses of the abyssinones and discovery of new inhibitors of prostate cancer and MMP-2 expression. ACS Med Chem Lett 2010; 1: 400-5.

57 Hu LH, Qin ZL, Li C, Huang Q, Wang FH. Synthesis and fungicidal activity of flavanone derivatives containing isopentene group. Chin J Appl Chem 2003; 20: 1161-5.

58 Pelter A, Ward RS, Ashdown DHJ. The synthesis of mono-, di-, and trihydroxyisoflavones. Synthesis 1978; 1978: 843.

59 Tsukayama M, Kawamura Y, Tamaki H, Horie T. Synthesis of parvisoflavones A and B. Chem Pharm Bull 1991; 39: 1704-6.

60 Yang JH, Zhao YM, Ji CB. First total synthesis of ( \pm )-abyssinoflavanone V. Chin Chem Lett 2008; 19: 658-60.

61 Rao GV, Swamy BN, Chandregowda V, Reddy GC. Synthesis of ( \pm )Abyssinone I and related compounds: Their anti-oxidant and cytotoxic activities. Eur J Med Chem 2009; 44: 2239-45.

62 Moriarty RM, Grubjesic S, Surve BC, Chandersekera SN, Prakash O, Naithani R. Synthesis of Abyssinone II and related compounds as potential chemopreventive agents. Eur J Med Chem 2006; 41: 263-7.

63 Maiti A, Cuendet M, Croy VL, Endringer DC, Pezzuto JM, Cushman M. Synthesis and biological evaluation of ( \pm )-abyssinone II and its analogues as aromatase inhibitors for chemoprevention of breast cancer. J Med Chem 2007; 50: 2799-806.

64 Mohamed SEN, Thomas P, Whiting DA. Synthesis of the phytoalexin ( \pm )-phaseollin: 3-phenylthiochromans as masked $2 \mathrm{H}$-chromenes and o-prenyl phenols. J Chem Soc, Perkin Trans 1 1987; 431-7.

$65 \mathrm{Na} \mathrm{M,} \mathrm{Kim} \mathrm{KA,} \mathrm{Oh} \mathrm{H,} \mathrm{Kim} \mathrm{BY,} \mathrm{Oh} \mathrm{WK,} \mathrm{Ahn} \mathrm{JS.} \mathrm{Protein} \mathrm{tyrosine}$ phosphatase $1 \mathrm{~B}$ inhibitory activity of amentoflavone and its cellular effect on tyrosine phosphorylation of insulin receptors. Biol Pharm Bull 2007; 30: 379-81.

66 Cui L, Na M, Oh H, Bae EY, Jeong DG, Ryu SE, et al. Protein tyrosine phosphatase $1 \mathrm{~B}$ inhibitors from Morus root bark. Bioorg Med Chem Lett 2006; 16: 1426-9.

67 Guo S, Li J, Li T, Shi D, Han L. Synthesis of three bromophenols from red algae as PTP1B inhibitors. Chin J Oceanol Limnol 2011; 29 : $68-74$.

68 Liu Q, Xu H, Zhang T, Fan X, Han L. A new compound as PTP1B inhibitor from the red alga Polysiphonia urceolata. Hua Xue Tong Bao 2006; 69: 708-10.

69 Shi D, Xu F, He J, Li J, Fan X, Han L. Inhibition of bromophenols against PTP1B and anti-hyperglycemic effect of Rhodomela confervoides extract in diabetic rats. Chin Sci Bull 2008; 53: 2476-9.

70 Shi DY, Xu F, Li J, Guo SJ, Su H, Han LJ. PTP1B inhibitory activities of bromophenol derivatives from algae. Zhongguo Zhong Yao Za Zhi 2008; 33: 2238-40.
71 Oh KB, Lee JH, Lee JW, Yoon KM, Chung SC, Jeon HB, et al. Synthesis and antimicrobial activities of halogenated bis(hydroxyphenyl) methanes. Bioorg Med Chem Lett 2009; 19: 945-8.

72 Oh KB, Jeon HB, Han YR, Lee YJ, Park J, Lee SH, et al. Bromophenols as Candida albicans isocitrate lyase inhibitors. Bioorg Med Chem Lett 2010; 20: 6644-8.

73 Qin J, Su H, Zhang Y, Gao J, Zhu L, Wu X, et al. Highly brominated metabolites from marine red alga Laurencia similis inhibit protein tyrosine phosphatase 1B. Bioorg Med Chem Lett 2010; 20: 7152-4.

74 Liu X, Li X, Gao L, Cui C, Li C, Li J, et al. Extraction and PTP1B inhibitory activity of bromophenols from the marine red alga Symphyocladia latiuscula. Chin J Oceanol Limnol 2011; 29: 686-90.

75 Balaydin HT, Akbaba Y, Menzek A, Şahin E, Göksu S. First and short syntheses of biologically active, naturally occurring brominated mono- and dibenzyl phenols. ARKIVOC 2009; 2009: 75-87.

76 Chung TW, Moon SK, Chang YC, Ko JH, Lee YC, Cho G, et al. Novel and therapeutic effect of caffeic acid and caffeic acid phenyl ester on hepatocarcinoma cells: complete regression of hepatoma growth and metastasis by dual mechanism. FASEB J 2004; 18: 1670-81.

77 He ZZ, Yan JF, Song ZJ, Ye F, Liao X, Peng SL, et al. Chemical constituents from the aerial parts of Artemisia minor. J Nat Prod 2009; 72: 1198-201.

78 Lee YS, Kang IJ, Won MH, Lee JY, Kim JK, Lim SS. Inhibition of protein tyrosine phosphatase $1 \beta$ by hispidin derivatives isolated from the fruiting body of Phellinus linteus. Nat Prod Commun 2010; 5 : 1927-30.

79 Yao XS, Li J, Hong K, Tang JS, Gao H, Gao LX, et al. Application of 2-acetylamino gentisic acid to preparing insulin sensitizer. China patent CN 101919835 A. 2010 December 22.

80 Seo C, Yim JH, Lee HK, Oh H. PTP1B inhibitory secondary metabolites from the Antarctic lichen Lecidella carpathica. Mycology 2011; 2: 18-23.

81 Seo C, Choi YH, Ahn JS, Yim JH, Lee HK, Oh H. PTP1B inhibitory effects of tridepside and related metabolites isolated from the Antarctic lichen Umbilicaria antarctica. J Enzyme Inhib Med Chem 2009; 24: 1133-7.

82 Seo C, Sohn JH, Ahn JS, Yim JH, Lee HK, Oh H. Protein tyrosine phosphatase $1 \mathrm{~B}$ inhibitory effects of depsidone and pseudodepsidone metabolites from the Antarctic lichen Stereocaulon alpinum. Bioorg Med Chem Lett 2009; 19: 2801-3.

83 Oh H, Kim BS, Bae EY, Kim MS, Kim BY, Lee HB, et al. Inhibition of PTP1B by metabolites from Micromucor ramannianus var angulisporus CRM000232. J Antibiot 2004; 57: 528-31.

84 Fürstner A, Konetzki I. Total synthesis of caloporoside. J Org Chem 1998; 63: 3072-80.

85 Fürstner A. Total syntheses and biological assessment of macrocyclic glycolipids. Eur J Org Chem 2004; 2004: 943-58.

86 Seo C, Sohn JH, Oh H, Kim BY, Ahn JS. Isolation of the protein tyrosine phosphatase $1 \mathrm{~B}$ inhibitory metabolite from the marine-derived fungus Cosmospora sp SF-5060. Bioorg Med Chem Lett 2009; 19: 6095-7.

87 Baumgartner RR, Steinmann D, Heiss EH, Atanasov AG, Ganzera M, Stuppner $\mathrm{H}$, et al. Bioactivity-guided isolation of 1,2,3,4,6-pentaO-galloyl-D-glucopyranose from Paeonia lactiflora roots as a PTP1B inhibitor. J Nat Prod 2010; 73: 1578-81.

88 Baumgartner RR, Steinmann D, Heiss EH, Atanasov AG, Ganzera M, Stuppner $\mathrm{H}$, et al. Bioactivity-guided isolation of 1,2,3,4,6-pentaO-galloyl-D-glucopyranose from Paeonia lactiflora roots as a PTP1B inhibitor. J Nat Prod 2010; 73: 1742.

89 Na M, Hoang DM, Njamen D, Mbafor JT, Fomum ZT, Thuong PT, et al. Inhibitory effect of 2-arylbenzofurans from Erythrina addisoniae on 
protein tyrosine phosphatase-1B*. Bioorg Med Chem Lett 2007; 17: 3868-71.

90 Feng Y, Carroll AR, Addepalli R, Fechner GA, Avery VM, Quinn RJ. Vanillic acid derivatives from the green algae Cladophora socialis as potent protein tyrosine phosphatase 1B inhibitors. J Nat Prod 2007; 70: 1790-2.

91 Seo C, Sohn JH, Park SM, Yim JH, Lee HK, Oh H. Usimines A-C, bioactive usnic acid derivatives from the Antarctic lichen Stereocaulon alpinum. J Nat Prod 2008; 71: 710-2.

92 Hawranik DJ, Anderson KS, Simmonds R, Sorensen JL. The chemoenzymatic synthesis of usnic acid. Bioorg Med Chem Lett 2009; 19: 2383-5.

93 Otani T, Sugimoto Y, Aoyagi Y, Igarashi Y, Furumai T, Saito N, et al. New Cdc25B tyrosine phosphatase inhibitors, nocardiones $A$ and B, produced by Nocardia sp TP-A0248: taxonomy, fermentation, isolation, structural elucidation and biological properties. J Antibiot 2000; 53: 337-44.

94 Tanada Y, Mori K. Synthesis and absolute configuration of nocardione A and B, furano-o-naphthoquinone-type metabolites of Nocardia $\mathrm{sp}$ with antifungal, cytotoxic, and enzyme inhibitory activities. Eur J Org Chem 2001; 2001: 4313-9.

95 Yang H, Lu W, Bao JX, Aisa HA, Cai JC. Total synthesis of ( \pm )-nocardione A and ( \pm )-nocardione B, two Cdc25B tyrosine phosphatase inhibitors. Chin Chem Lett 2001; 12: 883-6.

96 Clive DL, Fletcher SP. Synthesis of (+)-nocardione A - use of formal radical cyclization onto a benzene ring. Chem Commun 2003; (19): 2464-5.

97 Clive DL, Fletcher SP, Liu D. Formal radical cyclization onto benzene rings: A general method and its use in the synthesis of entnocardione A. J Org Chem 2004; 69: 3282-93.

98 Seo C, Choi YH, Sohn JH, Ahn JS, Yim JH, Lee HK, et al. Ohioensins F and G: Protein tyrosine phosphatase 1B inhibitory benzonaphthoxanthenones from the Antarctic moss Polytrichastrum alpinum. Bioorg Med Chem Lett 2008; 18: 772-5.

99 Wang Y, Shang XY, Wang SJ, Mo SY, Li S, Yang YC, et al. Structures, biogenesis, and biological activities of pyrano[4,3-c]isochromen-4one derivatives from the fungus Phellinus igniarius. J Nat Prod 2007; 70: 296-9.

100 Murray RD. Coumarins. Nat Prod Rep 1989; 6: 591-624.

101 Murray RDH. Coumarins. Nat Prod Rep 1995; 12: 477-505.

102 Estévez-Braun A, González AG. Coumarins. Nat Prod Rep 1997; 14: 465-75.

103 Umezawa T. Diversity in lignan biosynthesis. Phytochem Rev 2003; 2: 371-90.

104 Kim YC, Oh H, Kim BS, Kang TH, Ko EK, Han YM, et al. In vitro protein tyrosine phosphatase $1 \mathrm{~B}$ inhibitory phenols from the seeds of Psoralea corylifolia. Planta Med 2005; 71: 87-9.

105 Xiao K, Song QH, Zhang SW, Xuan LJ. Water-soluble constituents of the root barks of Fraxinus rhynchophylla (Chinese drug Qinpi). J Asian Nat Prod Res 2008; 10: 205-10.

106 Pahari P, Rohr J. Total synthesis of psoralidin, an anticancer natural product. J Org Chem 2009; 74: 2750-4.

107 Yang S, Min Kyun N, Jang JP, Kim KA, Kim BY, Sung NJ, et al. Inhibition of protein tyrosine phosphatase $1 B$ by lignans from Myristica fragrans. Phytother Res 2006; 20: 680-2.

108 He ZZ, Yan JF, Liao X, Zhang WY, Ji JX, Ding LS. Novel lignan compound and application thereof. China patent CN 101805325 A. 2010 August 18.

109 Takano S, Shimazaki Y, Ogasawara K. Enantiocontrolled synthesis of natural (+)-bakuchiol. Tetrahedron Lett 1990; 31: 3325-6.

110 Araki S, Bustugan Y. Short synthesis of ( \pm )-bakuchiol via a geranyl- indium reagent. J Chem Soc, Perkin Trans 1 1991; 2395-7.

$111 \mathrm{Du}$ XL, Chen HL, Feng HJ, Li YC. Stereoselective total synthesis of natural (S)-bakuchiol and its enantiomer. Helv Chim Acta 2008; 91 : 371-8.

112 Chen H, Li Y. Simple and convenient synthesis of ( \pm )-bakuchiol. Lett Org Chem 2008; 5: 467-9.

113 Esumi T, Shimizu H, Kashiyama A, Sasaki C, Toyota M, Fukuyama Y. Efficient construction of a chiral all-carbon quaternary center by asymmetric 1,4-addition and its application to total synthesis of (+)-bakuchiol. Tetrahedron Lett 2008; 49: 6846-9.

114 Bequette JP, Jungong CS, Novikov AV. Enantioselective synthesis of Bakuchiol using diazosulfonate $\mathrm{C}-\mathrm{H}$ insertion to install the quaternary center. Tetrahedron Lett 2009; 50: 6963-4.

115 Wang JD, Dong ML, Zhang W, Shen X, Guo YW. Chemical constituents of mangrove plant Lumnitzera racemosa. Chin J Nat Med 2006; 4: 185-7.

116 Arisawa M, Ohmura K, Kobayashi A, Morita N. A cytotoxic constituent of Lysimachia japonica THUNB. (Primulaceae) and the structureactivity relationships of related compounds. Chem Pharm Bull 1989; 37: 2431-4.

117 Kolev TM, Velcheva EA, Stamboliyska BA, Spiteller M. DFT and experimental studies of the structure and vibrational spectra of curcumin. Int J Quantum Chem 2005; 102: 1069-79.

118 Li JM, Li YC, Kong LD, Hu QH. Curcumin inhibits hepatic proteintyrosine phosphatase $1 \mathrm{~B}$ and prevents hypertriglyceridemia and hepatic steatosis in fructose-fed rats. Hepatology 2010; 51: 155566.

119 Pedersen U, Rasmussen PB, Lawesson SO. Synthesis of naturally occurring curcuminoids and related compounds. Liebigs Ann Chem 1985; 1985: 1557-69.

120 Qiu X, Du Y, Lou B, Zuo Y, Shao W, Huo Y, et al. Synthesis and identification of new 4-arylidene curcumin analogues as potential anticancer agents targeting nuclear factor-kB signaling pathway. J Med Chem 2010; 53: 8260-73.

121 Li YF, Hu LH, Lou FC, Li J, Shen Q. PTP1B inhibitors from Ardisia japonica. J Asian Nat Prod Res 2005; 7: 13-8.

122 Motoyoshiya J, Masue Y, Nishi Y, Aoyama H. Synthesis of hypericin via emodin anthrone derived from a two-fold Diels-Alder reaction of 1,4-benzoquinone. Nat Prod Commun 2007; 2: 67-70.

123 Li S, An TY, Li J, Shen Q, Lou FC, Hu LH. PTP1B inhibitors from Saussrurea lappa. J Asian Nat Prod Res 2006; 8: 281-6.

124 Ahmed SA, Bardshiri E, Simpson TJ. A convenient synthesis of isotopically labelled anthraquinones, chrysophanol, islandicin, and emodin. Incorporation of [methyl- ${ }^{2} \mathrm{H}_{3}$ ]chrysophanol into tajixanthone in Aspergillus variecolor. J Chem Soc, Chem Commun 1987; 12 : 883-4.

125 Nicoletti TM, Raston CL, Sargent MV. A new synthesis of anthraquinones using dihydro-oxazoles and Grignard reagents derived from Mg(anthracene)(THF) $)_{3}$. J Chem Soc, Perkin Trans 1 1990; 133-8.

126 Bae EY, Oh H, Oh WK, Kim MS, Kim BS, Kim BY, et al. A new VHR dual-specificity protein tyrosine phosphatase inhibitor from Dendrobium moniliforme. Planta Med 2004; 70: 869-70.

127 Paululat T, Kulik A, Hausmann H, Karagouni AD, Zinecker H, Imhoff JF, et al. Grecocyclines: New angucyclines from Streptomyces sp Acta 1362. Eur J Org Chem 2010; 2010: 2344-50.

128 Paduch R, Kandefer-Szerszeń M, Trytek M, Fiedurek J. Terpenes: substances useful in human healthcare. Arch Immunol Ther Exp 2007; 55: 315-27.

129 Wagner KH, Elmadfa I. Biological relevance of terpenoids. Ann Nutr Metab 2003; 47: 95-106.

130 Deng M, Dong W, Jiao W, Lu R. New eremophilane sesquiterpenes 
from the roots of Ligularia fischeri. Helv Chim Acta 2009; 92: 495501.

131 Shao ZY, Li J, Sim CJ, Li JY, Li ZY, Nan FJ, et al. 0-methyl nakafuran-8 lactone, a new sesquiterpenoid from a Hainan marine sponge Dysidea sp. J Asian Nat Prod Res 2006; 8: 223-7.

132 Huang XC, Li J, Li ZY, Shi L, Guo YW. Sesquiterpenes from the Hainan sponge Dysidea septosa. J Nat Prod 2008; 71: 1399-403.

$133 \mathrm{Li} \mathrm{Y,} \mathrm{Zhang} \mathrm{Y,} \mathrm{Shen} \mathrm{X,} \mathrm{Guo} \mathrm{YW.} \mathrm{A} \mathrm{novel} \mathrm{sesquiterpene} \mathrm{quinone} \mathrm{from}$ Hainan sponge Dysidea villosa. Bioorg Med Chem Lett 2009; 19: 390-2.

134 Uyehara T, Sugimoto M, Suzuki I, Yamamoto Y. Total synthesis of $( \pm)$-nakafuran-8, a marine metabolite with antifeedant properties, based on formal bridgehead substitution of a bicyclo[2.2.2]oct-5-en2-one system. J Chem Soc, Chem Commun 1989; 1841-2.

135 Uyehara T, Sugimoto M, Suzuki I, Yamamoto Y. Rearrangement approaches to cyclic skeletons. Part 8 . Total synthesis of ( \pm )-nakafuran-8, a marine metabolite with antifeedant properties, on the basis of bridgehead substitution of a bicyclo[2.2.2]oct-5-en-2-one system. J Chem Soc, Perkin Trans 1 1992; 1785-8.

136 Kurth MJ, Soares CJ. Asymmetric aza-Claisen rearrangement: Synthesis of (+)-dihydropallescensin-2 [(+)-penlanpallescensin]. Tetrahedron Lett 1987; 28: 1031-4.

137 Aisa A, Xin XL, Li YM; Lactucin and its preparation method and application. China patent CN 101099566 B. 2008 November 10.

138 Choi JY, Na M, Hwang IH, Lee SH, Bae EY, Kim BY, et al. Isolation of betulinic acid, its methyl ester and guaiane sesquiterpenoids with Protein Tyrosine Phosphatase 1B inhibitory activity from the roots of Saussurea lappa CB Clarke. Molecules 2009; 14: 266-72.

139 Rigby JH, Wilson JZ. Total synthesis of guaianolides: ( \pm )-dehydrocostus lactone and ( \pm )-estafiatin. J Am Chem Soc 1984; 106: 821724.

140 Yuuya S, Hagiwara H, Suzuki T, Ando M, Yamada A, Suda K, et al. Guaianolides as immunomodulators. Synthesis and biological activities of dehydrocostus lactone, mokko lactone, eremanthin, and their derivatives. J Nat Prod 1998; 62: 22-30.

$141 \mathrm{Fu} \mathrm{HZ}$, Luo YM, Li CJ, Yang JZ, Zhang DM. Psidials A-C, three unusual meroterpenoids from the leaves of Psidium guajava L. Org Lett 2010; 12: 656-9.

142 Kim S, Na M, Oh H, Jang J, Sohn CB, Kim BY, et al. PTP1B inhibitory activity of kaurane diterpenes isolated from Siegesbeckia glabrescens. J Enzyme Inhib Med Chem 2006; 21: 379-83.

$143 \mathrm{Na} \mathrm{M}$, Oh WK, Kim YH, Cai XF, Kim S, Kim BY, et al. Inhibition of protein tyrosine phosphatase $1 \mathrm{~B}$ by diterpenoids isolated from Acanthopanax koreanum. Bioorg Med Chem Lett 2006; 16: 30614.

144 Cui L, Wu X, An ZS, Li DH; Kaurane-type diterpenoid compound as well as preparation method and medical application thereof. China patent CN 101786953 A. 2010 July 28.

145 Cheng YX, Zhou WS. Study on the tetracyclic diterpenoids 5. Synthesis of ent-kaur-16-en-19-oic acid. Acta Chim Sinica 1993; 51: 819-24.

146 Ling T, Chowdhury C, Kramer BA, Vong BG, Palladino MA, Theodorakis EA. Enantioselective synthesis of the antiinflammatory agent (-)-acanthoic acid. J Org Chem 2001; 66: 8843-53.

147 Han YM, Oh H, Na M, Kim BS, On WK, Kim BY, et al. PTP1B inhibitory effect of abietane diterpenes isolated from Salvia miltiorrhiza. Biol Pharm Bull 2005; 28: 1795-7.

148 Kakisawa H, Inouye Y. Total syntheses of tanshinone-I, tanshinone-II, and cryptotanshinone. Chem Commun (London) 1968; 1327-8.

149 Marrero JG, Andrés LS, Luis JG. Quinone derivatives by chemical transformations of 16-hydroxycarnosol from Salvia species. Chem
Pharm Bull 2005; 53: 1524-9.

150 Kate AS, Aubry I, Tremblay ML, Kerr RG. Lipidyl pseudopteranes A-F: isolation, biomimetic synthesis, and PTP1B inhibitory activity of a new class of pseudopteranoids from the Gorgonian Pseudopterogorgia acerosa. J Nat Prod 2008; 71: 1977-82.

151 Iguchi K, Shimada Y, Yamada Y. Hyrtiosal, a new sesterterpenoid with a novel carbon skeleton from the Okinawan marine sponge Hyrtios erectus. J Org Chem 1992; 57: 522-4.

152 Sun T, Wang Q, Yu Z, Zhang Y, Guo Y, Chen K, et al. Hyrtiosal, a PTP1B inhibitor from the marine sponge Hyrtios erectus, shows extensive cellular effects on PI3K/AKT activation, glucose transport, and TGFB/Smad2 signaling. ChemBioChem 2007; 8: 187-93.

153 Du L, Shen L, Yu Z, Chen J, Guo Y, Tang Y, et al. Hyrtiosal, from the marine sponge Hyrtios erectus, inhibits HIV-1 integrase binding to viral DNA by a new inhibitor binding site. ChemMedChem 2008; 3: 173-80.

154 Basabe P, Diego A, Díez D, Marcos IS, Urones JG. Synthesis and absolute configuration of (-)-hyrtiosal. Synlett 2000; 2000: 1807-9.

155 Basabe P, Diego A, Díez D, Marcos IS, Mollinedo F, Urones JG. Hyrtiosanes from labdanes: (-)-hyrtiosal from sclareol. Synthesis 2002; 2002: 1523-9.

156 Lunardi I, Santiago GMP, Imamura PM. Synthesis of (-)- and (+)-hyrtiosal and their C-16 epimers. Tetrahedron Lett 2002; 43: 3609-11.

157 Cao S, Foster C, Lazo JS, Kingston DG. Sesterterpenoids and an alkaloid from a Thorectandra sp as inhibitors of the phosphatase Cdc25B. Bioorg Med Chem 2005; 13: 5094-8.

158 Boukouvalas J, Robichaud J, Maltais F. A unified strategy for the regiospecific assembly of homoallyl-substituted butenolides and y-hydroxybutenolides: First synthesis of luffariellolide. Synlett 2006; 2006: 2480-2.

159 Wright AE, McCarthy PJ, Schulte GK. Sulfircin: a new sesterterpene sulfate from a deep-water sponge of the genus Ircinia. J Org Chem 1989; 54: 3472-4.

160 Na M, Cui L, Min BS, Bae K, Yoo JK, Kim BY, et al. Protein tyrosine phosphatase $1 \mathrm{~B}$ inhibitory activity of triterpenes isolated from Astilbe koreana. Bioorg Med Chem Lett 2006; 16: 3273-6.

$161 \mathrm{Na} \mathrm{M}$, Yang S, He L, Oh H, Kim BS, Oh WK, et al. Inhibition of protein tyrosine phosphatase $1 \mathrm{~B}$ by ursane-type triterpenes isolated from Symplocos paniculata. Planta Med 2006; 72: 261-3.

162 Shi L, Zhang W, Zhou YY, Zhang YN, Li JY, Hu LH, et al. Corosolic acid stimulates glucose uptake via enhancing insulin receptor phosphorylation. Eur J Pharmacol 2008; 584: 21-9.

163 Ma M, Wang SJ, Li S, Yang YC, Shi JG, Ye F, et al. Triterpenes with protein tyrosine phosphotase $1 \mathrm{~B}$ inhibitory activity from Macaranga adenantha. Zhongcaoyao 2006; 37: 1128-31.

164 Qian S, Li H, Chen Y, Zhang W, Yang S, Wu Y. Synthesis and biological evaluation of oleanolic acid derivatives as inhibitors of protein tyrosine phosphatase 1B. J Nat Prod 2010; 73: 1743-50.

165 Qiu WW, Shen Q, Yang F, Wang B, Zou H, Li JY, et al. Synthesis and biological evaluation of heterocyclic ring-substituted maslinic acid derivatives as novel inhibitors of protein tyrosine phosphatase 1B. Bioorg Med Chem Lett 2009; 19: 6618-22.

166 Corey EJ, Lee J. Enantioselective total synthesis of oleanolic acid, erythrodiol, $\beta$-amyrin, and other pentacyclic triterpenes from a common intermediate. J Am Chem Soc 1993; 115: 8873-4.

167 Ramírez-Espinosa JJ, Rios MY, López-Martínez S, López-Vallejo $\mathrm{F}$, Medina-Franco JL, Paoli $\mathrm{P}$, et al. Antidiabetic activity of some pentacyclic acid triterpenoids, role of PTP-1B: In vitro, in silico, and in vivo approaches. Eur J Med Chem 2011; 46: 2243-51.

168 Zhang P, Hao J, Liu J, Zhang L, Sun H. Efficient synthesis of morolic 
acid and related triterpenes starting from betulin. Tetrahedron 2009; 65: 4304-9.

169 Flekhter O, Medvedeva N, Tolstikov GA, Galin F, Yunusov M, Mai H, et al. Synthesis of olean-18(19)-ene derivatives from betulin. Russ J Bioorg Chem 2009; 35: 233-9.

170 Xu W, Zhu C, Cheng W, Fan X, Chen X, Yang S, et al. Chemical constituents of the roots of Euphorbia micractina. J Nat Prod 2009; 72: $1620-6$.

171 Kwon JH, Chang MJ, Seo HW, Lee JH, Min BS, Na M, et al. Triterpenoids and a sterol from the stem-bark of Styrax japonicaand their protein tyrosine phosphatase $1 \mathrm{~B}$ inhibitory activities. Phytother Res 2008; 22: 1303-6.

172 Na M, Thuong PT, Hwang IH, Bae K, Kim BY, Osada H, et al. Protein tyrosine phosphatase $1 \mathrm{~B}$ inhibitory activity of 24-norursane triterpenes isolated from Weigela subsessilis. Phytother Res 2010; 24 : 1716-9.

$173 \mathrm{Na} \mathrm{M,} \mathrm{Kim} \mathrm{BY,} \mathrm{Osada} \mathrm{H,} \mathrm{Ahn} \mathrm{JS.} \mathrm{Inhibition} \mathrm{of} \mathrm{protein} \mathrm{tyrosine} \mathrm{phos-}$ phatase $1 \mathrm{~B}$ by lupeol and lupenone isolated from Sorbus commixta. J Enzyme Inhib Med Chem 2009; 24: 1056-9.

174 Csuk R, Schmuck K, Schäfer R. A practical synthesis of betulinic acid. Tetrahedron Lett 2006; 47: 8769-70.

175 Surendra K, Corey EJ. A short enantioselective total synthesis of the fundamental pentacyclic triterpene lupeol. J Am Chem Soc 2009; 131: 13928-9.

176 Hung TM, Hoang DM, Kim JC, Jang HS, Ahn JS, Min BS. Protein tyrosine phosphatase $1 \mathrm{~B}$ inhibitory by dammaranes from Vietnamese Giao-Co-Lam tea. J Ethnopharmacol 2009; 124: 240-5.

177 Hanson JR. Steroids: partial synthesis in medicinal chemistry. Nat Prod Rep 2010; 27: 887-99.

178 Lee HS, Hwang IH, Kim JA, Choi JY, Jang TS, Osada H, et al. Isolation of protein tyrosine phosphatase $1 \mathrm{~B}$ inhibitory constituents from the sclerotia of Polyporus umbellatus Fries. Bull Korean Chem Soc 2011; 32: 697-700.

179 Wang L, Chen B, Shen XR, Zhou YY, Jiang DW, Li J, et al. Growth inhibition and induction of early apoptosis by arenicolsterol $A$, a novel cytotoxic enolic sulphated sterol from the marine annelid, Arenicola cristata. J Asian Nat Prod Res 2007; 9: 753-61.

180 Wang JR, Shen Q, Fang L, Peng SY, Yang YM, Li J, et al. Structural and stereochemical studies of five new pregnane steroids from the stem bark of Toona ciliata var pubescens. Steroids 2011; 76: 571-6.

181 Yan XH, Guo YW, Zhu XZ. Chemical constituents of the gorgonian Muricella sinensis (Verrill). Nat Prod Res Dev 2005; 17: 412-4.

182 Singh TV, Kaur R, Agnihotri KR, Bali M. Synthesis of calicoferol E. ARKIVOC 2002; 2002: 82-90.

183 Piao SJ, Zhang HJ, Lu HY, Yang F, Jiao WH, Yi YH, et al. Hippolides $\mathrm{A}-\mathrm{H}$, acyclic manoalide derivatives from the marine sponge Hippospongia lachne. J Nat Prod 2011; 74: 1248-54.

184 Mao SC, Guo YW, Shen X. Two novel aromatic valerenane-type sesquiterpenes from the Chinese green alga Caulerpa taxifolia. Bioorg Med Chem Lett 2006; 16: 2947-50.

185 Wikipedia. Berberine. Available from: http://en.wikipedia.org/wiki/ Berberine.

186 Bustanji Y, Taha MO, Yousef AM, AI-Bakri AG. Berberine potently inhibits protein tyrosine phosphatase 1B: Investigation by docking simulation and experimental validation. J Enzyme Inhib Med Chem 2006; 21: 163-71.

187 Chen C, Zhang Y, Huang C. Berberine inhibits PTP1B activity and mimics insulin action. Biochem Biophys Res Commun 2010; 397: 543-7.

188 Wikipedia. Papaverine. Available from: http://en.wikipedia.org/wiki/ Papaverine.
189 Bustanji Y, Taha MO, Al-masri IM, Mohammad MK. Docking simulations and in vitro assay unveil potent inhibitory action of papaverine against protein tyrosine phosphatase 1B. Biol Pharm Bull 2009; 32 : 640-5.

190 Hohmann C, Schneider K, Bruntner C, Brown R, Jones AL, Goodfellow $\mathrm{M}$, et al. Albidopyrone, a new $\alpha$-pyrone-containing metabolite from marine-derived Streptomyces sp NTK 227. J Antibiot 2009; 62: 75-9.

191 Schulz D, Nachtigall J, Riedlinger J, Schneider K, Poralla K, Imhoff $\mathrm{JF}$, et al. Piceamycin and its $\mathrm{N}$-acetylcysteine adduct is produced by Streptomyces sp GB 4-2*. J Antibiot 2009; 62: 513-8.

192 Seo C, Yim JH, Lee HK, Park SM, Sohn JH, Oh H. Stereocalpin A, a bioactive cyclic depsipeptide from the Antarctic lichen Stereocaulon alpinum. Tetrahedron Lett 2008; 49: 29-31.

193 Ghosh AK, Xu CX. A convergent synthesis of the proposed structure of antitumor depsipeptide stereocalpin A. Org Lett 2009; 11: 19636.

194 Choi YH, Sohn JH, Lee D, Kim JK, Kong IS, Ahn SC, et al. Chejuenolides $A$ and $B$, new macrocyclic tetraenes from the marine bacterium Hahella chejuensis. Tetrahedron Lett 2008; 49: 712831.

195 Sun YQ, Guo YW. Gymnorrhizol, an unusual macrocyclic polydisulfide from the Chinese mangrove Bruguiera gymnorrhiza. Tetrahedron Lett 2004; 45: 5533-5.

196 Sun YQ, Sun J, Guo YW. Crystal structure of 1,2,6,7,11,12-hexathiacyclopentadecane, C9H18S6. Z Kristallogr - NCS 2004; 219: 11920.

197 Gong JX, Shen X, Yao LG, Jiang H, Krohn K, Guo YW. Total synthesis of gymnorrhizol, an unprecedented 15-membered macrocyclic polydisulfide from the Chinese mangrove Bruguiera gymnorrhiza. Org Lett 2007; 9: 1715-6.

198 Huang XY, Wang Q, Liu HL, Zhang Y, Xin GR, Shen X, et al. Diastereoisomeric macrocyclic polydisulfides from the mangrove Bruguiera gymnorrhiza. Phytochemistry 2009; 70: 2096-100.

199 Hamaguchi T, Sudo T, Osada H. RK-682, a potent inhibitor of tyrosine phosphatase, arrested the mammalian cell cycle progression at $\mathrm{G}_{1}$ phase. FEBS Lett 1995; 372: 54-8.

200 Sodeoka M, Sampe R, Kagamizono T, Osada H. Asymmetric synthesis of RK-682 and its analogs, and evaluation of their protein phosphatase inhibitory activities. Tetrahedron Lett 1996; 37: 87758.

201 Shinagewa S, Muroi M, Ito T, Hida T; Tetronic acid derivative, its production and use. Japan patent JP 05-43568 A. 1993 February 23.

202 Mittra A, Yamashita M, Kawasaki I, Murai H, Yoshioka T, Ohta S. A useful oxidation procedure for the preparation of 3-alkanoyltetronic acids. Synlett 1997; 1997: 909-10.

203 Schobert R, Jagusch C. Solution-phase and solid-phase syntheses of enzyme inhibitor RK-682 and antibiotic agglomerins. J Org Chem 2005; 70: 6129-32.

204 Helaly S, Schneider K, Nachtigall J, Vikineswary S, Tan GY, Zinecker $\mathrm{H}$, et al. Gombapyrones, new $\alpha$-pyrone metabolites produced by Streptomyces griseoruber Acta 3662*. J Antibiot 2009; 62: 44552.

205 Alvi KA, Nair BG, Rabenstein J, Davis G, Baker DD. CD45 tyrosine phosphatase inhibitory components from Aspergillus niger. J Antibiot 2000; 53: 110-3.

206 Seibert SF, Eguereva E, Krick A, Kehraus S, Voloshina E, Raabe G, et al. Polyketides from the marine-derived fungus Ascochyta salicorniae and their potential to inhibit protein phosphatases. Org Biomol Chem 2006; 4: 2233-40. 
207 Galbraith MN, Whalley WB. The synthesis of ( \pm )-ascochitine. Chem Commun (London) 1966; 620a-a.

208 Wang JD, Dong ML, Zhang W, Shen X, Guo YW. Chemical constituents of mangrove plant Aegiceras corniculatum. Chin J Nat Med 2006; 4: 275-7.

209 Zheng G, Lu W, Cai J. Stereoselective total synthesis of $(3 R, 8 S)$ falcarindiol, a common polyacetylenic compound from umbellifers. J Nat Prod 1999; 62: 626-8.

210 Sabitha G, Bhaskar V, Reddy CS, Yadav JS. Stereoselective approaches for the total synthesis of polyacetylenic $(3 R, 8 S)$-falcarindiol. Synthesis 2008; 2008: 115-21.

211 Schmiech L, Alayrac C, Witulski B, Hofmann T. Structure determination of bisacetylenic oxylipins in carrots (Daucus carota L) and enantioselective synthesis of falcarindiol. J Agric Food Chem 2009; 57: 11030-40.

212 Tamura S, Ohno T, Hattori Y, Murakami N. Establishment of absolute stereostructure of falcarindiol, algicidal principle against Heterocapsa circularisquama from Notopterygii Rhizoma. Tetrahedron Lett 2010;
51: 1523-5.

213 Li YF, Li J, Shen Q, Hu LH. Benzoquinones from Ardisia japonica with inhibitory activity towards human protein tyrosine phosphatase $1 \mathrm{~B}$ (PTP1B). Chem Biodivers 2007; 4: 961-5.

214 Yadav JS, Upender V, Rao AVR. A practical preparation of functionalized alkylbenzoquinones: synthesis of maesanin and irisquinone. J Org Chem 1992; 57: 3242-5.

215 Poigny S, Guyot M, Samadi M. Total synthesis of maesanin and analogues. Tetrahedron 1998; 54: 14791-802.

216 Pfeifer J, Gerlach H. Synthese von naturstoffen mit alkyl-methoxy1,4-benzochinon-struktur. Liebigs Ann 1995; 1995: 131-7.

217 Tsukamoto S, Takeuchi S, Ishibashi M, Kobayashi J. Manzamenones A-F from the Okinawan marine sponges Plakortis sp: novel dimeric fatty acid derivatives possessing a bicyclo[4.3.0]nonane skeleton. J Org Chem 1992; 57: 5255-60.

218 Wakuda Y, Kubota T, Shima H, Okada T, Mitsuhashi S, Aoki N, et al. Manzamenones Inhibit T-Cell Protein Tyrosine Phosphatase. Mar Drugs 2006; 4: 9-14. 